\title{
Transient thermal modeling of permafrost conditions in Southern Norway
}

\author{
S. Westermann, T. V. Schuler, K. Gisnås, and B. Etzelmüller \\ Department of Geosciences, University of Oslo, P.O. Box 1047, Blindern, 0316 Oslo, Norway
}

Correspondence to: S. Westermann (sebastian.westermann@geo.uio.no)

Received: 3 December 2012 - Published in The Cryosphere Discuss.: 20 December 2012

Revised: 19 March 2013 - Accepted: 4 April 2013 - Published: 25 April 2013

\begin{abstract}
Thermal modeling is a powerful tool to infer the temperature regime of the ground in permafrost areas. We present a transient permafrost model, CryoGrid 2, that calculates ground temperatures according to conductive heat transfer in the soil and in the snowpack. CryoGrid 2 is forced by operational air temperature and snow-depth products for potential permafrost areas in Southern Norway for the period 1958 to 2009 at $1 \mathrm{~km}^{2}$ spatial resolution. In total, an area of about $80000 \mathrm{~km}^{2}$ is covered. The model results are validated against borehole temperatures, permafrost probability maps from "bottom temperature of snow" measurements and inventories of landforms indicative of permafrost occurrence. The validation demonstrates that CryoGrid 2 can reproduce the observed lower permafrost limit to within $100 \mathrm{~m}$ at all validation sites, while the agreement between simulated and measured borehole temperatures is within $1 \mathrm{~K}$ for most sites. The number of grid cells with simulated permafrost does not change significantly between the 1960s and 1990s. In the 2000 s, a significant reduction of about $40 \%$ of the area with average $2 \mathrm{~m}$ ground temperatures below $0{ }^{\circ} \mathrm{C}$ is found, which mostly corresponds to degrading permafrost with still negative temperatures in deeper ground layers. The thermal conductivity of the snow is the largest source of uncertainty in CryoGrid 2, strongly affecting the simulated permafrost area. Finally, the prospects of employing CryoGrid 2 as an operational soil-temperature product for Norway are discussed.
\end{abstract}

\section{Introduction}

Permafrost is a key element of the cryosphere and has hence been included in the Global Climate Observing System (GCOS) as an "Essential Climate Variable" for terrestrial systems (gcos.wmo.int, 2012), which constitutes the obligation to continuously monitor its state variables.

Until 2100, a considerable degradation of permafrost is projected as a consequence of global warming (e.g., Delisle, 2007; Lawrence et al., 2008), which includes both a reduction of the areal extent and a deepening of the active layer in the remaining permafrost areas. Such predictions are in line with current measurements of permafrost temperatures in boreholes, which have become more numerous in most areas over the last decades (e.g., Romanovsky et al., 2010; Christiansen et al., 2010). While boreholes are an efficient means to access and monitor soil temperatures, they are costly to establish and maintain, so that their number will remain limited. Thus, it is problematic to extrapolate borehole temperatures to larger unmonitored regions. This is especially true for permafrost areas with strong climatic and altitudinal gradients and/or a strong heterogeneity of the surface cover, where a large number of boreholes would be required to achieve a sufficiently detailed areal coverage.

Thermal permafrost models based on conductive heat transfer have proven to be powerful tools to describe the vertical distribution of soil temperatures (e.g., Zhang et al., 2003; Jafarov et al., 2012). They are generally forced by time series of surface meteorological variables, such as air temperature and snow height, which can be derived from a number of sources, for example in situ measurements at meteorological stations or atmospheric circulation models. With gridded data sets of these variables, maps of permafrost temperatures can be created through modeling, which can complement point measurements in boreholes. Few studies have been able to specify the uncertainty of such model results due to deficiencies in the model physics and uncertainties in the forcing data sets and model parameters. Here, particularly 
regional studies at high spatial resolution offer the potential to compare model results with borehole data and unfold the impact of different parameters and their combinations on the accuracy of the model results.

In Southern Norway, permafrost is restricted to mountain regions and high plateaus. A strong temperature and precipitation gradient from west to east and a wide range of subsurface materials make it a challenging area for permafrost modeling. On the other hand, gridded data sets of meteorological variables based on interpolation of in situ measurements are readily available (e.g., Mohr, 2008), so that the area constitutes an ideal region to assess the performance of thermal permafrost modeling. Furthermore, modeling studies suggest a considerable reduction of the permafrost area over the past decades (Hipp et al., 2012; Gisnås et al., 2013) that has not been documented with in situ borehole measurements, which can be further investigated and quantified by spatially distributed modeling of the permafrost thermal dynamics.

The regional distribution of permafrost in Southern Norway is relatively well known, based on field investigations (e.g., Farbrot et al., 2011), bottom temperature of winter snow cover (BTS) surveys (e.g., Heggem et al., 2005; Isaksen et al., 2002), landform inventories (Lilleøren and Etzelmüller, 2011) and equilibrium permafrost modeling (Gisnås et al., 2013). In general, the lower limit of discontinuous mountain permafrost decreases in elevation from west (approx. $1600 \mathrm{~m}$ a.s.l.) to east (approx. $1200 \mathrm{~m}$ a.s.l.) (Etzelmüller et al., 2003b). Permafrost is mainly restricted to areas above the tree line and sporadic occurrences in palsa mires, which exist below 1000 ma.s.l. in Southern Norway (e.g., Sollid and Sørbel, 1998).

We present the modeled permafrost thermal dynamics for Southern Norway at a resolution of $1 \mathrm{~km}^{2}$ for the $50 \mathrm{yr}$ period 1960-2009, based on a transient thermal permafrost model, CryoGrid 2, and gridded data sets of air temperature and snow depth. Furthermore, we establish accuracy margins for the results by conducting a thorough validation and provide a detailed analysis of the sources of uncertainty. Finally, the prospects of an operational ground temperature product for Norway are discussed, which would be highly beneficial for the monitoring goals of GCOS.

\section{The CryoGrid 2 model}

CryoGrid 2 is a numerical framework to infer time series of ground temperatures based on the surface variables air (or surface) temperature and snow depth. Other than the equilibrium model CryoGrid 1 (Gisnås et al., 2013), which is designed to reproduce permafrost parameters for equilibrium climate conditions, CryoGrid 2 can deliver the transient response of ground temperatures to a changing climate. Its model physics is similar to other widely employed permafrost models, such as GIPL2 (Geophysical Institute Per- mafrost Lab 2) (e.g., Jafarov et al., 2012): the change of internal energy and temperature in the ground is entirely determined by Fourier's law of heat conduction, and the latent heat generated/consumed by soil freezing/thawing. Movement of water or water vapor in the ground is not included, so that the soil water content can only change over time due to freezing processes. For spatially distributed modeling, the target domain is decomposed in grid cells, for which all model variables and parameters are assumed to be constant. In each grid cell, only heat flow in the vertical direction is considered, thus solving an effective $1 \mathrm{D}$ problem and neglecting lateral heat flow between neighboring cells. This is justified for grid cell sizes considerably larger than the extent of the vertical modeling domain. In the following Sects. 2.1 to 2.3, the defining equations for a single grid cell are presented. We distinguish the soil domain below the ground surface (positive vertical coordinates $z$ ) and the snow domain located above (negative $z$ ).

\subsection{Soil and snow thermal model}

In the soil domain, temperature $T$ changes over time $t$ and depth $z$ through heat conduction as only a physical process, as described by (Jury and Horton, 2004)

$c_{\text {eff }}(z, T) \frac{\partial T}{\partial t}-\frac{\partial}{\partial z}\left(k(z, T) \frac{\partial T}{\partial z}\right)=0$,

where $k(z, T)\left(\mathrm{W} \mathrm{m}^{-1} \mathrm{~K}^{-1}\right)$ denotes the thermal conductivity and $c_{\text {eff }}\left(\mathrm{J} \mathrm{m}^{-3} \mathrm{~K}^{-1}\right)$ the effective volumetric heat capacity, which accounts for the latent heat of freezing and melting of water/ice as follows:

$c_{\text {eff }}=c(T, z)+L \frac{\partial \theta_{\mathrm{w}}}{\partial T}$.

$\theta_{\mathrm{w}}$ denotes the volumetric water content, and $L=334 \mathrm{MJ}$ $\mathrm{m}^{-3}$ the specific volumetric latent heat of fusion of water. The first term is calculated from the volumetric fractions of the constituents as follows:

$c(T, z)=\sum_{\alpha} \theta_{\alpha}(T, z) c_{\alpha}$,

where $\theta_{\alpha}(-)$ and $c_{\alpha}\left(\mathrm{J} \mathrm{m}^{-3} \mathrm{~K}^{-1}\right)$ represent the volumetric contents and the specific volumetric heat capacities (following Hillel, 1982) of the constituents water, ice, air, mineral and organic, $\alpha=w, i, a, m, o$.

The thermal conductivity of the soil $k$ is calculated from the volumetric fractions $\theta_{\alpha}$ of the soil constituents water, ice, air, mineral and organic, $\alpha=w, i, a, m, o$, as (Cosenza et al., 2003):

$k=\left(\sum_{\alpha} \theta_{\alpha} \sqrt{k_{\alpha}}\right)^{2}$.

The temperature-dependence of the thermal conductivity, which gives rise to the thermal offset between ground surface 
and permafrost temperatures (Osterkamp and Romanovsky, 1999), is hereby contained in the temperature-dependent water and ice contents as detailed in Sect. 2.2. The parameterization according to Eq. (4) is chosen for simplicity (other parameterizations are e.g., de Vries, 1952; Farouki, 1981), as reliable validation studies and thus recommendation for a particular conductivity model are lacking for permafrost areas so far.

In the snow domain, heat conduction is the only process of energy transfer considered in CryoGrid 2, similar to Eq. (1). The snowpack is considered "dry", i.e., production, infiltration and refreezing of melt (and rain) water are not considered. The thermal conductivity and volumetric heat capacity of the snowpack, $k_{\text {snow }}$ and $c_{\text {snow }}$, are assumed to be constant in time and space (see Sect. 3.3). The volumetric heat capacity is calculated from the densities $\rho$ of snow and ice as follows:

$c_{\text {snow }}=\frac{\rho_{\text {snow }}}{\rho_{\text {ice }}} c_{i}$.

\subsection{Soil freezing characteristic}

The soil freezing characteristic $\theta_{\mathrm{w}}(T)$ is based on Dall'Amico et al. (2011), who relate soil freezing to its hydraulic properties based on the assumption that freezing has the same effect on the soil water potential as drying (see also Daanen et al., 2008; Daanen and Nieber, 2009). The soil water retention curve is parameterized according to Mualem (1976) and Van Genuchten (1980): the soil water potential in unfrozen state, $\psi_{\mathrm{w} 0}(\mathrm{~m})$, is expressed as a function of the volumetric soil water content $\theta_{\mathrm{w}}$, the saturated volumetric soil water content $\theta_{\mathrm{ws}}$ (corresponding to one minus soil porosity) and the residual volumetric soil water content in frozen state, $\theta_{\mathrm{wr}}=\theta_{\mathrm{w}}\left(T \ll 0^{\circ} \mathrm{C}\right)$ as:

$\psi_{\mathrm{w} 0}=-\frac{1}{\alpha}\left[\left(\frac{\theta_{\mathrm{w}}-\theta_{\mathrm{wr}}}{\theta_{\mathrm{ws}}-\theta_{\mathrm{wr}}}\right)^{\frac{n}{1-n}}-1\right]^{\frac{1}{n}}$,

where $\alpha\left(\mathrm{m}^{-1}\right)$ and $n(-)$ are parameters related to the soil type. Note that $\psi_{\mathrm{w} 0}$ becomes zero for saturated conditions. For unsaturated conditions, the temperature $T^{*}$ below which soil water starts to freeze is depressed below the freezing point of free water, $T_{\mathrm{f}}=0^{\circ} \mathrm{C}$, as:

$T^{*}=T_{\mathrm{f}}+\frac{g T_{\mathrm{f}}}{L} \psi_{\mathrm{w} 0}$,

where $g=9.81 \mathrm{~m} \mathrm{~s}^{-2}$ denotes the standard acceleration of gravity. Accordingly, the soil water potential $\psi(T)$ decreases linearly with temperature for temperatures below $T^{*}$ :

$\psi(T)= \begin{cases}\psi_{\mathrm{w} 0}+\frac{L}{g T^{*}}\left(T-T^{*}\right) & \text { for } T \leq T^{*} \\ \psi_{\mathrm{w} 0} & \text { for } T>T^{*} .\end{cases}$

A detailed derivation of Eqs. (7) and (8) is provided by Dall'Amico et al. (2011). Using the temperaturedependent soil water potential $\psi(T)$ (Eq. 8), the soil freezing characteristic $\theta_{\mathrm{w}}(T)$ is again obtained by the Mualem-van Genuchten model as following:

$\theta_{\mathrm{w}}(T)=\theta_{\mathrm{wr}}+\left(\theta_{\mathrm{ws}}-\theta_{\mathrm{wr}}\right)\left(1+[-\alpha \psi(T)]^{n}\right)^{1-\frac{1}{n}}$.

Note that $\theta_{\mathrm{w}}(T)$ is fully defined for given values of $\theta_{\mathrm{ws}}, \theta_{\mathrm{wr}}$ and $\theta_{\mathrm{w}}\left(T>0{ }^{\circ} \mathrm{C}\right)$ through Eqs. (6) to (9). The volumetric ice content is hence given by

$\theta_{i}(T)=\theta_{\mathrm{ws}}-\theta_{\mathrm{w}}(T)$.

In CryoGrid 2, we distinguish three soil types, sand, silt and clay, for which the values of $\alpha, n$ and $\theta_{\mathrm{wr}}$ are chosen according to Dall' Amico et al. (2011).

\subsection{Numerical solution}

The heat transfer equation (Eq. 1) is numerically solved for a soil domain with $100 \mathrm{~m}$ depth using the method of lines (Schiesser, 1991). Central finite differences are employed to discretize the spatial derivatives $\partial / \partial z$ on a grid, while the time $t$ is left as a continuous variable. In doing so, derivatives are replaced by difference quotients, with temperatures assigned to the midpoint of a grid cell and fluxes to the boundary between two cells. This procedure yields a system of coupled ordinary differential equations (ODE) with time as only variable. The ODE system is solved numerically with the ODE-solver package CVODE of Sundials (SUite of Nonlinear and DIfferential/ALgebraic equation Solvers) (Hindmarsh et al., 2005), which minimizes computational costs through adaptive integration time steps. In CVODE, we use a backward differentiation formula method whose order is automatically adapted between 1 and 5 to guarantee stability. To account for larger temperature gradients closer to the surface, the grid spacing $\Delta z$ increases with depth: $0.05 \mathrm{~m}$ between the surface (defined as $0 \mathrm{~m}$ ) and $1.6 \mathrm{~m}, 0.2 \mathrm{~m}$ between $1.6 \mathrm{~m}$ and $5.0 \mathrm{~m}, 0.5 \mathrm{~m}$ between $5.0 \mathrm{~m}$ and $20.0 \mathrm{~m}$, $1.0 \mathrm{~m}$ between $20.0 \mathrm{~m}$ and $30.0 \mathrm{~m}, 5.0 \mathrm{~m}$ between $30.0 \mathrm{~m}$ and $50.0 \mathrm{~m}$ and $10.0 \mathrm{~m}$ between $50.0 \mathrm{~m}$ and $100.0 \mathrm{~m}$. At the upper boundary, a Dirichlet boundary condition is applied by specifying a time series of temperature, denoted $T_{\mathrm{ub}}(t)$, for a fictitious grid cell (size $0.05 \mathrm{~m}$ ) on top of the uppermost regular grid cell, while a constant heat flux, denoted $F_{\mathrm{lb}}$, is specified at the lower boundary (taken as the bottom of the lowermost grid cell).

For non-zero snow depths, the top position of the spatial grid is adapted for each time step based on a specified time series of snow depths. For this purpose, grid cells with a grid spacing of $0.05 \mathrm{~m}$ are added on top of the soil domain up to the position closest to the snow depth for the respective time step. When a new grid cell is added from one time step to the next, the temperature of the newly added grid cell $T_{+}$is obtained from the defining differential equation:

$\frac{\partial T_{+}}{\partial t}=\frac{T_{\mathrm{ub}}(t)-T_{+}}{\tau_{+}}$, 
which ensures that $T_{+}$follows the temperature at the upper boundary with a characteristic lag time $\tau_{+}$. We set $\tau_{+}$to the characteristic timescale of heat diffusion through snow over the grid spacing $\Delta z$ :

$\tau_{+}=\frac{c_{\text {snow }}(\Delta z)^{2}}{k_{\text {snow }}}$.

With this choice, the integration time step selected by the ODE solver is optimal both for the defining equations of ground temperatures (Eq. 1) and $T_{+}$(Eq. 11). Note that the uppermost grid cell can simply be removed, if the number of snow cells decreases between time steps (i.e., for decreasing snow depths).

\section{Model operation}

\subsection{Surface forcing and boundary conditions}

For mainland Norway, gridded data sets of air temperature and snow depth (in the following denoted "Senorge data") are operationally provided by the Norwegian Meteorological Institute (Mohr, 2008; Mohr and Tveito, 2008; Tveito and Førland, 1999) and the Norwegian Water and Energy Directorate (Engeset et al., 2004a,b; Saloranta, 2012) at a spatial resolution of $1 \mathrm{~km}^{2}$ and daily temporal resolution. The Senorge data set is based on interpolations of in situ measurements at meteorological stations distributed across Norway, which take into account the topography through monthly varying lapse rates (Mohr and Tveito, 2008). For the air temperature, the lapse rate varies as a function of altitude, average altitude of a larger area surrounding the station and geographical coordinates. The precipitation is increased by $10 \%$ per $100 \mathrm{~m}$ elevation increase from $0 \mathrm{~m}$ to $1000 \mathrm{~m}$ a.s.l., and by $5 \%$ per $100 \mathrm{~m}$ above $1000 \mathrm{~m}$ a.s.l. At air temperatures of less than $0.5^{\circ} \mathrm{C}$, precipitation is considered snow, which allows calculating the snow water equivalent (SWE) from precipitation and temperature data. The snow depth is subsequently calculated from SWE by taking into account snow melt, snow accumulation and compaction (Engeset et al., 2004a,b).

The Senorge time series of air temperature is used as upper boundary condition for Eq. (1), while the position of the uppermost grid cell is determined from the record of snow depths (see Sect. 2.3). To increase the computational efficiency, we employ weekly averages of air temperature and snow depth to force the model. In case of non-zero snow depths and positive air temperature, i.e., during periods of snow melt, the temperature is set to $0{ }^{\circ} \mathrm{C}$.

As lower boundary condition at a depth of $100 \mathrm{~m}$, the geothermal heat flux is used. For each Senorge grid cell, a separate value is obtained by interpolating the heat flow map for Fennoscandia and the Norwegian-Greenland Sea provided by Slagstad et al. (2009).

\subsection{Ground properties}

The surface geology is based on a vector map of the major surface sediment classes by the Norwegian Geological Survey (NGU, 2010; Thoresen, 1990), gridded to $1 \mathrm{~km}^{2}$ resolution by assigning the sediment class with the largest aerial fraction to each cell. The map is mainly based on air photo interpretation and higher-resolution mapping in different areas of Norway, and thus constitutes a detailed basis describing upper ground properties. The surface sediments are classified based on genesis rather than on grain size. Furthermore, the thickness of the sediments are not given explicitly and are only qualitatively distinguished. As both granulometry/porosity and thickness of surface sediments are crucial for their ability to hold water and thus ice in permafrost regions, this characteristic highly influences the transient ground thermal behavior, and a stratigraphy based on subjective interpretation had to be done for each sediment class (Table 1).

Surface sediments in central Southern Norway are dominated by till (moraine material; 50\%) (e.g., Sollid and Sørbel, 1984) followed by exposed bedrock (32\%). Organic material covers about $6 \%$, and forms the largest of the minor classes. Weathered material, which includes block fields, are below $5 \%$. For the largest group, till, the following characteristics can be stated:

- In general, the tills in Southern Norway are relatively thin, mostly below 5 to $10 \mathrm{~m}$ (e.g., Jørgensen, 1977), depending on the relative position in the terrain (e.g., Garnes and Bergersen, 1977). Larger till thicknesses are observed close to ice-marginal positions. However, since the mountains in Southern Norway have been at or close to the ice-divide, till thicknesses are generally moderate. Over large areas till is shallow and below $1 \mathrm{~m}$ in thickness (approx. 20\%).

- The tills are mainly coarse-grained with dominance of sand and gravel and only a small clay content (e.g., Carlson and Sollid, 1983; Jørgensen, 1977), since the till has been transported only short distances and hard crystalline bedrock dominates in Southern Norway (e.g., Jørgensen, 1977; Vorren, 1977). Furthermore, subglacial crushing dominated over abrasion because of the close vicinity to the ice divide and thus limited basal sliding, reducing the production of silt and clay-sized erosion products (Haldorsen, 1981).

We distinguish two till thickness classes: thick tills/ marginal deposits (10 m thickness, $40 \%$ porosity) and thin till ( $1 \mathrm{~m}$ thickness, $40 \%$ porosity). We assume a water/ice content of $30 \%$ as an annual average (Table 1) as some silt and clay in the tills increase the field capacity, and precipitation is generally high in the study area.

Organic material and mires are crucial for the ground thermal regime. The accumulation of organic material was only active since deglaciation between 8 and $10 \mathrm{Kyr}$ BP (before 
present) in many areas, so that it is relatively shallow in comparison to areas that were never glaciated. We distinguish between thick, organic material above minerogenic material ( $10 \mathrm{~m}$ thickness, porosity of $50 \%$ down to $2 \mathrm{~m}$, organic content of $30 \%)$ and organic material over bedrock (50\% porosity, $0.5 \mathrm{~m}$ thickness).

Sorted sandy to gravelly sediments are mainly associated with glacio-fluvial and modern fluvial deposits. The glacio-fluvial sediments are mostly deposited during the last phase of deglaciation in Southern Norway and may dominate shallow depression and valley settings even in higher mountain areas, e.g., in central Southern Norway (e.g., Sollid and Reite, 1983). These areas have a low water holding capacity and are dry towards the surface, with saturated conditions in some depth depending on topographic position. We distinguish relatively thick glacio-fluvial and fluvial material (20 m thickness, $40 \%$ porosity, dry upper layers with $10 \%$ water content) from relatively thin modern fluvial deposits with the same characteristics of the upper layers as the previous class.

Gravitational material mapped includes all types of landslide deposits and is therefore very difficult to classify in terms of ground properties. In general, gravitational materials in Norwegian mountains are talus slopes, colluvial deposits from debris-flow activity (e.g., Blikra et al., 1989) or large, blocky remnants from late-glacial or early Holocene rock slides (Bergsturz) (e.g., Blikra and Anda, 1997). Talus areas are restricted in size, and Bergsturz deposits are mostly situated in lower elevations and therefore of low interest for permafrost. Colluvial deposits are in contrary wide-spread and relevant in high-mountain areas like in Jotunheimen (Blikra and Nemec, 1998; Matthews et al., 1997). Those deposits are removed lateral till deposits, unsorted and similar to basal tills. Therefore, we used the same ground properties as for thick till deposits.

In situ-weathered material is associated with high-lying plateau areas (peneplains) in Southern Norway, underlying presumably a cold ice sheet setting with limited glacial erosion (e.g., Etzelmüller et al., 2007, 2003b). In these areas, coarse blocky surfaces often dominate. For our modeling we assumed an average thickness of $5 \mathrm{~m}$ and $40 \%$ porosity, but low water/ice content within the upper $2 \mathrm{~m}$ (Table 1). Block fields often have lower grain sizes with depth and become water saturated at a certain depth (e.g., Roaldset et al., 1982). Ordinary in situ-weathered materials have similar properties, but are less than $5 \mathrm{~m}$ thick.

The thermal conductivity of the mineral fraction of the soil, $k_{\mathrm{m}}$ (see Eq. 4), is compiled for each grid cell from maps of bedrock classes (Sigmond, 2002) and approx. 2000 point measurements of bedrock thermal conductivity provided by the Norwegian Geological Survey (NGU) (Olesen et al., 2010). These point data were assigned to the different bedrock classes in the map, and an average value was calculated for each class. The thermal conductivities of all other soil constituents as well as the volumetric heat capacities
Table 1. Sediment stratigraphies assumed in CryoGrid 2, with volumetric fractions of the soil constituents and soil type for each layer given. The class numbers refer to the employed sediment map (NGU, 2010; Thoresen, 1990).

\begin{tabular}{|c|c|c|c|c|c|}
\hline depth $[\mathrm{m}]$ & water/ice & mineral & organic & air & type \\
\hline \multicolumn{6}{|c|}{ Till and coarse colluvium (diamicton), thick: classes $11,15,81$} \\
\hline $0-2$ & 0.3 & 0.6 & 0.0 & 0.1 & sand \\
\hline $2-10$ & 0.4 & 0.6 & 0.0 & 0.0 & sand \\
\hline$>10$ & 0.03 & 0.97 & 0.0 & 0.0 & sand \\
\hline \multicolumn{6}{|c|}{ Till and coarse colluvium (diamicton), thin: classes 12,140} \\
\hline $0-1$ & 0.3 & 0.6 & 0.0 & 0.1 & sand \\
\hline$>1$ & 0.03 & 0.97 & 0.0 & 0.0 & sand \\
\hline \multicolumn{6}{|c|}{ Bedrock: class 130} \\
\hline$>0$ & 0.03 & 0.97 & 0.0 & 0.0 & sand \\
\hline \multicolumn{6}{|c|}{ Glacio-fluvial sand/gravel: classes 20, 21} \\
\hline $0-1$ & 0.1 & 0.6 & 0.0 & 0.3 & sand \\
\hline $1-20$ & 0.4 & 0.6 & 0.0 & 0.0 & sand \\
\hline$>20$ & 0.03 & 0.97 & 0.0 & 0.0 & sand \\
\hline \multicolumn{6}{|c|}{ Esker (sand/gravel): class 22} \\
\hline $0-5$ & 0.1 & 0.6 & 0.0 & 0.3 & sand \\
\hline$>5$ & 0.03 & 0.97 & 0.0 & 0.0 & sand \\
\hline \multicolumn{6}{|c|}{ Recent fluvial sand/gravel: class 50} \\
\hline $0-1$ & 0.1 & 0.6 & 0.0 & 0.3 & sand \\
\hline $1-10$ & 0.4 & 0.6 & 0.0 & 0.0 & sand \\
\hline$>10$ & 0.03 & 0.97 & 0.0 & 0.0 & sand \\
\hline \multicolumn{6}{|c|}{ Regolith (coarse), thin: class 70} \\
\hline $0-1$ & 0.1 & 0.6 & 0.0 & 0.3 & sand \\
\hline $1-2$ & 0.4 & 0.6 & 0.0 & 0.0 & sand \\
\hline$>2$ & 0.03 & 0.97 & 0.0 & 0.0 & sand \\
\hline \multicolumn{6}{|c|}{ Regolith (coarse), thick: class 71} \\
\hline $0-1$ & 0.1 & 0.6 & 0.0 & 0.3 & sand \\
\hline $1-5$ & 0.4 & 0.6 & 0.0 & 0.0 & sand \\
\hline$>5$ & 0.03 & 0.97 & 0.0 & 0.0 & sand \\
\hline \multicolumn{6}{|c|}{ Block fields: class 73} \\
\hline $0-2$ & 0.1 & 0.6 & 0.0 & 0.3 & sand \\
\hline $2-5$ & 0.4 & 0.6 & 0.0 & 0.0 & sand \\
\hline$>5$ & 0.03 & 0.97 & 0.0 & 0.0 & sand \\
\hline \multicolumn{6}{|c|}{ Organic accumulation (bogs and mires): class 90} \\
\hline $0-0.5$ & 0.3 & 0.2 & 0.3 & 0.2 & sand \\
\hline $0.5-2$ & 0.5 & 0.2 & 0.3 & 0.0 & sand \\
\hline $2-10$ & 0.5 & 0.4 & 0.1 & 0.0 & silt \\
\hline$>10$ & 0.03 & 0.97 & 0.0 & 0.0 & sand \\
\hline \multicolumn{6}{|c|}{ Thin organic cover over bedrock or shallow regolith: class 100} \\
\hline $0-0.5$ & 0.5 & 0.5 & 0.1 & 0.0 & sand \\
\hline$>0.5$ & 0.03 & 0.97 & 0.0 & 0.0 & sand \\
\hline
\end{tabular}

are based on literature values (Hillel, 1982). For all bedrock types a constant porosity ( $3 \%$ ) and saturated water/ice conditions are assumed, which is in agreement with previous modeling studies of permafrost temperatures in different bedrock types (Hipp et al., 2012; Farbrot et al., 2011). 


\subsection{Snow properties}

Density: The snow density was measured in March 2011 at three permafrost monitoring sites, Juvflye (4 sample sites), Jetta ( 2 sample sites) and Tron (4 sample sites), which are located across the southern Norwegian continentality gradient and are thus a good representation of snow conditions in Southern Norway's permafrost region (Sect. 3.6). At each sample site, a profile of snow densities was gravimetrically determined in increments of $10 \mathrm{~cm}$. All sample sites are located above the tree line and featured hardpacked, wind-blown snow as typical for such locations in Southern Norway. The average density was determined to $(376 \pm 38) \mathrm{kg} \mathrm{m}^{-3}$ at Juvflye, $(398 \pm 40) \mathrm{kg} \mathrm{m}^{-3}$ at Jetta, and $(333 \pm 38) \mathrm{kg} \mathrm{m}^{-3}$ at Tron. Although single layers with above- or below-average densities were found, the snow densities did not increase towards the bottom of the snowpack in a statistically significant way. Thus, the snowpack is considered homogeneous with respect to density for modeling purposes, which is most likely explained by compaction of the snowpack due to the considerable wind drift at the sites. Furthermore, our measurements suggest that strong spatial differences between the three permafrost monitoring sites do not occur. Thus, a constant snow density of $\rho_{\text {snow }}=350 \mathrm{~kg} \mathrm{~m}^{-3}$ for the entire $\mathrm{S}$ Norway permafrost region is assumed in the simulations, corresponding to a volumetric heat capacity of $c_{\text {snow }}=0.75 \mathrm{MJ} \mathrm{m}^{-3}$. This assumption may not be accurate for area below tree line, where wind redistribution of snow is less pronounced. However, we are confident that it is a good representation of snow densities above tree line, where the largest part of the permafrost areas is located.

Thermal conductivity: In the absence of in situ measurements, an "effective" thermal conductivity was determined by fitting the CryoGrid 2 model to measured time series of ground temperatures at borehole sites with a snow cover exceeding $0.5 \mathrm{~m}$ height. For this purpose, CryoGrid 2 was adapted to run for a period of one year for a soil domain of $1.0 \mathrm{~m}$ with a measured time series of ground temperatures as lower boundary condition and a measured ground temperature profile as initial condition. As forcing data sets, we employed measured air temperatures and snow depths, as well as borehole temperatures at $1.0 \mathrm{~m}$ depth. Based on field knowledge from the borehole stratigraphy, an initial guess of the volumetric soil water and mineral contents of the uppermost $1 \mathrm{~m}$ of soil was made (the organic content was set to zero, and the sediment type to "sand"). We then ran 1000 model realizations for random perturbations of soil water and mineral content $( \pm 0.25$ around the initial guess) and snow thermal conductivity (between 0.1 and $0.7 \mathrm{~W} \mathrm{~m}^{-1} \mathrm{~K}^{-1}$ ), and calculated the resulting root mean square error (RMSE) between modeled and measured temperatures for three to four depths between 0.1 and $0.8 \mathrm{~m}$. This procedure was performed for, in total, five borehole sites on Juvflye, Jetta and Tron (one or two winter seasons each). For the ten realizations that best fit the data, the RMSE was between 0.15 and $0.4 \mathrm{~K}$ for all boreholes and years. The average snow thermal conductivity of these ten best realizations for all years and boreholes was $0.38 \mathrm{~W} \mathrm{~m}^{-1} \mathrm{~K}^{-1}$, and about two thirds of the values were contained in the interval between 0.3 and $0.5 \mathrm{~W} \mathrm{~m}^{-1} \mathrm{~K}^{-1}$. A regional east-west trend could not be discerned, but for single boreholes a strong variability between years was found. We therefore assume the range between 0.3 and $0.5 \mathrm{~W} \mathrm{~m}^{-1} \mathrm{~K}^{-1}$ to be a good representation of an effective snow thermal conductivity in the mountain regions of Southern Norway, which is in good agreement with in situ measurements in Western Svalbard for a similar climate forcing (Westermann et al., 2009). The resulting interval of snow thermal conductivities is regarded as parameter uncertainty, and we perform a low $\left(k_{\text {snow }}=0.3 \mathrm{Wm}^{-1} \mathrm{~K}^{-1}\right)$ and a high $\left(k_{\text {snow }}=0.5 \mathrm{~W} \mathrm{~m}^{-1} \mathrm{~K}^{-1}\right)$ conductivity scenario run of CryoGrid 2 as a confining range for the true conditions.

3 D effects in blocky surfaces: In areas with coarse blocky surface material (i.e., "block fields"), boulders and rocks will protrude the snow cover and facilitate direct heat conduction from the surface into the ground, thus bypassing the insulating snow cover. Since an accurate physically-based representation of this effect is not possible in a $1 \mathrm{D}$ scheme, we resort to a phenomenological description and reduce the snow depth by a constant, prescribed value of $0.5 \mathrm{~m}$, which is oriented at typical sizes of boulders in block fields. Thus, the build-up of the snow cover is effectively delayed in the modeling scheme until the snow height of the forcing data exceeds the threshold value, and the snow depth assumed in the model subsequently is $0.5 \mathrm{~m}$ lower than given by the forcing data. To distinguish coarse blocky surfaces, we employ the classification of Gisnås et al. (2013) based on a supervised classification of Landsat images. Note that this surface classification can in some cases deviate from the sediment class "block field" (see Table 1), which is based on the subsurface properties (Sect. 3.2).

\subsection{Model initialization}

The model is initialized to equilibrium conditions for the first five years of Senorge data, from July 1958 to June 1963, in the following denoted as "initialization forcing". To minimize the computational effort, we follow a five-step procedure: (1) initialize the ground profile to a steady state based on the values for the geothermal heat flux, the thermal conductivity and the average air temperature of the initialization forcing as temperature of the uppermost grid cell; (2) run the model twice with the initialization forcing, with the last ground temperature profile of the last day of the first run being the initial condition for the second run; (3) using the record of ground surface temperature (GST; taken as the temperature of the first soil grid cell) of the second run of step 2 , calculate the freezing and thawing degree days, FDD and 
TDD, as:

$\mathrm{FDD}=\int_{\mathrm{GST} \leq 0^{\circ} \mathrm{C}}^{t} \mathrm{GST} \mathrm{d} t$

$\mathrm{TDD}=\int_{\mathrm{GST}>0{ }^{\circ} \mathrm{C}}^{t} \mathrm{GST} \mathrm{d} t$,

where $t$ represents time and the integral runs over the full $5 \mathrm{yr}$ period. With the average thermal conductivity of the uppermost $2 \mathrm{~m}$ of the ground in fully thawed and fully frozen state, $k_{\mathrm{t}}$ and $k_{\mathrm{f}}$, and $\tau=5 \mathrm{yr}$, the top-of-permafrost (or top of seasonally frozen ground) temperature TTOP is calculated as (Smith and Riseborough, 1996):

$$
\mathrm{TTOP}=\left\{\begin{array}{l}
\tau^{-1}\left(\mathrm{FDD}+\frac{k_{\mathrm{t}}}{k_{\mathrm{f}}} \mathrm{TDD}\right) \text { for }-k_{\mathrm{f}} \mathrm{FDD} \geq k_{\mathrm{t}} \mathrm{TDD} \\
\tau^{-1}\left(\frac{k_{\mathrm{f}}}{k_{\mathrm{t}}} \mathrm{FDD}+\mathrm{TDD}\right) \text { for }-k_{\mathrm{f}} \mathrm{FDD}<k_{\mathrm{t}} \mathrm{FDD} ;
\end{array}\right.
$$

(4) repeat step 1 with TTOP as temperature of the uppermost soil cell; (5) run the model twice with the initialization forcing, as in step 2. The temperature profile of the last day is subsequently used as initial condition for the main model run forced by the entire time series of Senorge data. This procedure ensures that the insulating effect of the snow cover and the thermal offset is reflected in the temperatures of the deep ground layers (through steps 2 to 4). Through step 5, which represents a ten year model spin-up, the annual temperature cycle of the upper ground layers is reproduced. Applying the top-of-permafrost temperature at the surface and not at typical depths of a few meters (steps 3 and 4) inflicts an error in the steady-state temperature profile on the order of $0.1 \mathrm{~K}$ for typical values of the geothermal heat flux and the thermal conductivity of the ground. However, this uncertainty must be considered negligible as the model initialization with equilibrium conditions cannot account for the transient nature of the ground temperatures anyway. We thus emphasize that the modeled ground temperatures, in particular for the earlier periods (e.g., 1960-1969, see Sects. 4 and 5.1), will be influenced by the choice of the initialization, while the results become more reliable for later periods.

\subsection{Model implementation}

The CryoGrid 2 model is implemented for the potential permafrost areas in Norway, south of $63.5^{\circ} \mathrm{N}$ (approximately the latitude of the city of Trondheim, see Fig. 1). The spatial resolution of the model run is $1 \mathrm{~km}^{2}$ and the model period is 1958 to 2010, both of which are determined by the availability of the Senorge forcing data sets. As potential permafrost areas, we consider areas with mean annual air temperatures of the initialization period (Sect. 3.4) of less than $0^{\circ} \mathrm{C}$. Towards the coastal areas, where large altitudinal and thus temperature differences exist, the model domain was confined by a sharp boundary (see Fig. 3). In total, the model domain comprises about $80000 \mathrm{~km}^{2}$, corresponding to 80000 independent runs of CryoGrid 2. The average computation time for each grid cell on an Intel E5-2670 (Sandy Bridge) processor at $2.6 \mathrm{GHz}$ is on the order of $80 \mathrm{~s}$ for the model configuration described above. Using parallel computing, an efficient and timely execution of CryoGrid 2 is possible even for a large number of grid cells.

\subsection{Field installations and validation data sets}

Shallow boreholes with temperature measurements exist along altitudinal transects at three locations in Southern Norway, at Juvflye $\left(62^{\circ} \mathrm{N}, 8^{\circ} \mathrm{E}\right)$, Jetta $\left(62^{\circ} \mathrm{N}, 9^{\circ} \mathrm{E}\right)$ close to the Gudbrandsdalen Valley and the Tron massif $\left(62^{\circ} \mathrm{N}, 11^{\circ} \mathrm{E}\right)$ (Farbrot et al., 2011) (Fig.1). In all three areas snow cover is thin or absent at exposed sites due to wind erosion, while large snow thickness may exist in topographic lee sides. The tree line in all areas is at approx. 1000-1100 m a.s.l. At all borehole sites, the snow depth has been monitored with the method of Lewkowicz (2008) using vertical arrays of iButton temperature sensors (Hipp, 2012). Crucial properties of all boreholes employed for model validation are summarized in Table 2.

The Juvflye area is located in central Jotunheimen, comprising the highest mountain area of Norway (Galdhøpiggen 2469 ma.s.1.). The bedrock at Juvflye is part of a large plate of crystalline rocks (Jotun Nappe) of Precambrian age. Block fields are present down to $1600 \mathrm{~m}$ a.s.l. Seven boreholes exist in the area, with the PACE (Permafrost and Climate in Europe) borehole on Juvvasshøe (129 m deep at $1894 \mathrm{~m}$ a.s.l.) having a time series starting in 2000 (Harris et al., 2001; Isaksen et al., 2007). The six other boreholes (Juv-BH1-BH6) are all $10 \mathrm{~m}$ in depth and are located between $1851 \mathrm{~m}$ a.s.l. and $1307 \mathrm{~m}$ a.s.l. One of the boreholes (BH4) is drilled in pure bedrock, while the sediment properties of the other boreholes are given in Table 2.

Jetta (peak at $1617 \mathrm{~m}$ a.s.l.) belongs to the upper parts of the Kvitvola Nappe, consisting of late Precambrian sedimentary rocks. Openwork block fields are present down to 1500 and $1100 \mathrm{~m}$ a.s.l. on the northern and southern slopes, respectively, with thicknesses of 3-10 m (B $\varnothing, 1998)$. At Jetta three boreholes were drilled in bedrock between $1560 \mathrm{~m}$ a.s.l. and $1218 \mathrm{~m}$ a.s.l. (Table 2) (Farbrot et al., 2011).

The Tron massif (peak at $1666 \mathrm{~m}$ a.s.l.) consists of a layered mafic intrusion, containing dunites and olivine-bearing gabbros. Block fields dominate the surface material cover down to elevations of $1300-1450$ m a.s.l., depending on aspect, and are typically a few meters thick. Three boreholes were drilled between $1640 \mathrm{~m}$ a.s.l. and $1290 \mathrm{~m}$ a.s.l. The two uppermost boreholes are drilled in a block field, while the lowermost borehole is drilled in a sand-rich ground moraine. The uppermost borehole (Tron-BH1) was drilled in a center of a sorted polygon, in silt-rich sediments of high water content.

All boreholes were drilled in August 2008 using a core drill ( $45 \mathrm{~mm}$ diameter) at the four bedrock sites and hammer drills (115-130 $\mathrm{mm}$ diameter) at the eight sites with surficial 
Table 2. Comparison of measured borehole temperatures and modeled temperatures. As Senorge grid cell representative for a borehole site, the one with altitude closest to the borehole altitude in a $3 \mathrm{~km}$ by $3 \mathrm{~km}$ region around the borehole site is chosen. Ground conditions: conditions at the borehole and sediment class (Table 1) assumed in the model; snow: --: much less than, -: less than, 0: comparable to Senorge snow data; GT $2 \mathrm{~m}$ : average ground temperature at $2 \mathrm{~m}$ depth September 2008 to August 2010. For the model run, the values for low snow conductivity are displayed, the values for the high-conductivity run are about 0.5 to $1.0 \mathrm{~K}$ lower; *: only September 2009 to August 2009.

\begin{tabular}{lcclrrrr}
\hline ID & \multicolumn{2}{c}{$\begin{array}{c}\text { Elevation (m a.s.l.) } \\
\text { true }\end{array}$} & model & true & Ground conditions & snow & \multicolumn{2}{c}{ GT $2 \mathrm{~m}\left({ }^{\circ} \mathrm{C}\right)$} \\
& & 1890 & Block field & 130 & -- & -2.7 & -2.9 \\
\hline PACE & 1894 & 1860 & 130 & -- & -1.9 & -2.9 \\
Juv-BH1 & 1851 & 1860 & Block field & 11 & 0 & $-0.33^{*}$ & $-2.0^{*}$ \\
Juv-BH2 & 1771 & 1700 & Block field & 11 & -- & -0.7 & 0.0 \\
Juv-BH3 & 1561 & 1540 & Ground moraine, block-rich & 11 & -- & -0.8 & 2.0 \\
Juv-BH4 & 1559 & 1420 & Bedrock & 11 & - & 0.7 & 2.0 \\
Juv-BH5 & 1458 & 1420 & Ground moraine, sand/gravel & 11 & 1.8 \\
Juv-BH6 & 1307 & 1314 & Ground moraine, sand/gravel & 11 & 0 & 1.8 & 1.6 \\
\hline Jet-BH1 & 1560 & 1480 & Bedrock & 12 & 0 & -0.3 & 1.3 \\
Jet-BH2 & 1450 & 1420 & Bedrock & 12 & 0 & 0.9 & 1.4 \\
Jet-BH3 & 1218 & 1263 & Bedrock & 12 & -- & 1.0 & 1.9 \\
\hline Tron-BH1 & 1640 & 1580 & Block field & & 0 & 0.3 & 0.1 \\
& & & & 12 & 0 & 0.8 & PF at $10 \mathrm{~m}$ at $10 \mathrm{~m}$ \\
Tron-BH2 & 1589 & 1580 & Block field & 12 & - & 1.3 & 1.3 \\
Tron-BH3 & 1290 & 1290 & Ground moraine & & & & \\
\hline
\end{tabular}

sediments. Borehole depths varied from 9.5 to $30 \mathrm{~m}$, and all were cased with plastic tubing (PE40 and PE75 mm, respectively). The boreholes were equipped with various types of temperature loggers, all having an accuracy of $0.2 \mathrm{~K}$ or better. Average recorded ground temperatures at $2 \mathrm{~m}$ depths since 2008 varied from $-2.5^{\circ} \mathrm{C}$ at the highest elevation of the Juvflye area to $1.5^{\circ} \mathrm{C}$ at the lower-most borehole there. For more details on the data set, see Farbrot et al. (2011) and Hipp et al. (2012).

\section{Model results}

\subsection{Model validation}

\subsubsection{Permafrost temperatures and observations}

Point measurements of permafrost temperatures and model simulations for $1 \mathrm{~km}^{2}$ grid cells operate on different spatial scales, so that a direct comparison is not necessarily meaningful. However, especially borehole arrays that extend over a number of model grid cells can deliver gradients of important permafrost variables in dependence of environmental factors, such as altitude and sediment types. We compare the results of CryoGrid 2 to borehole arrays in Juvflye, Jetta and Tron (Sect. 3.6), which are located across an west-east transect and thus allow model validation from more maritime to more continental climate conditions. In addition, observations of the lower permafrost limit at sites in Dovrefjell, Sølen and Elgåhøgna are compared to the model results.
Table 2 displays a comparison of measured and modeled ground temperatures at a depth of $2 \mathrm{~m}$ for the borehole arrays at Juvflye (PACE (Permafrost and Climate in Europe), JuvBH1-Juv-BH6), Jetta (Jet-BH1-Jet-BH3) and Tron (Tron$\mathrm{BH} 1-$ Tron-BH3). The comparison is performed for $2 \mathrm{yr}$ averages at the end of the model period, which allows a good assessment of the model performance in reproducing the current thermal state of the permafrost. At Juvflye, the lowconductivity simulation of CryoGrid 2 places the lower limit of the permafrost at an altitude of approximately 1450 to $1550 \mathrm{~m}$ a.s.l., which is in good agreement with the in situ measurements (Farbrot et al., 2011). In the high-conductivity simulation, the lower permafrost limit is about $100 \mathrm{~m}$ lower, so that the low-conductivity run significantly better fits the observations. A comparison of borehole temperatures reveals deviations of up to $1.5 \mathrm{~K}$. At the two uppermost boreholes (PACE and Juv-BH1), the modeled ground temperatures are cold biased, although the snow depth at the borehole sites is significantly lower than in the Senorge data set due to wind drift of the snow. However, the sediment classification assumes bedrock in the corresponding grid cell, while in reality the uppermost $3-5 \mathrm{~m}$ consist of blocks at both borehole sites. A CryoGrid 2 run with sediment class 11 (till and coarse colluvium, thick, Table 1), which is in much better agreement with the borehole stratigraphies, for this grid cell yields a $2 \mathrm{~m}$ ground temperature of $-2.1^{\circ} \mathrm{C}$ instead of $-2.9^{\circ} \mathrm{C}$, which comes closer to the observations. However, in the light of the much shallower snow cover, a cold bias of the model remains for the uppermost two boreholes. A similar cold bias exists for Juv-BH2, where the snow depths at 


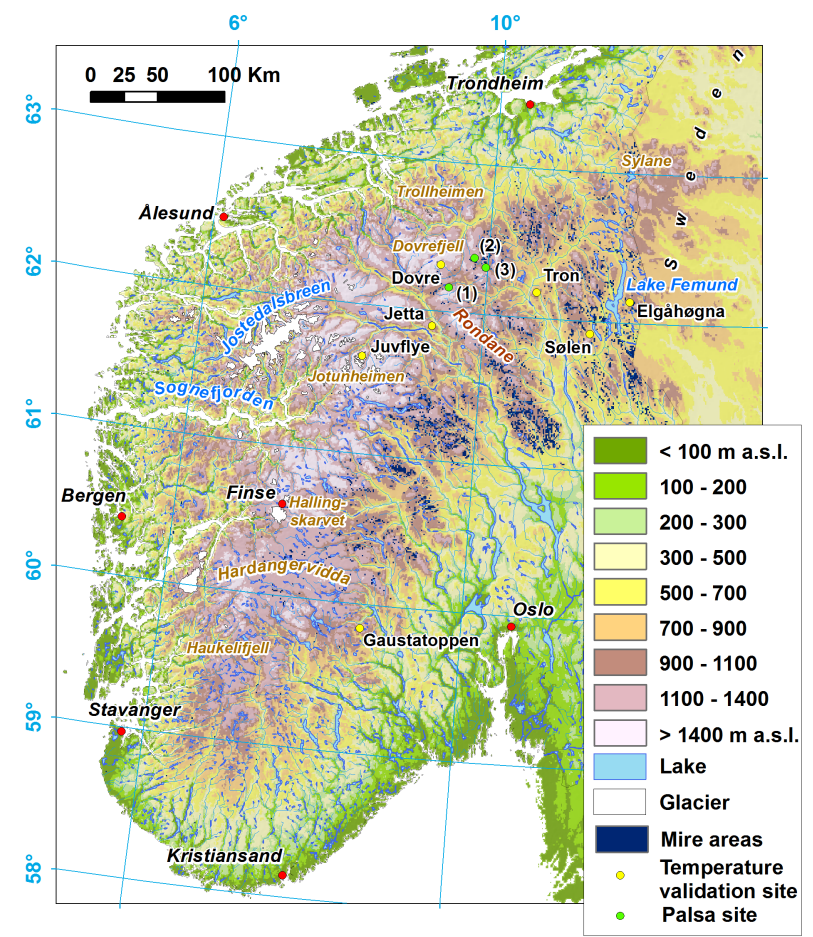

Fig. 1. The wider area in Southern Norway covered by the CryoGrid 2 simulations. The locations of the key validation sites at Juvflye, Jetta, Dovre, Tron, Sølen, Elgåhøgna and Gaustatoppen (Sect. 4.1) are marked. Areas classified as mires (sediment code 90) are highlighted and palsa mires used for validation (Sect. 4.1.3) marked by numbers: (1) Haukskardsmyra, (2) Haugtjørnin, (3) Dalsætra.

the borehole were comparable to the Senorge data (at least in the reference period 2008-2010). In addition, the elevation of the Senorge grid cell is about $70 \mathrm{~m}$ lower than the borehole altitude, so that the cold bias is even stronger than suggested by the CryoGrid 2 simulation. The next borehole, Juv$\mathrm{BH} 3$ is placed at the thawing threshold by the model, while the measured ground temperatures are still colder. The snow depth at the borehole site is much lower than in the Senorge data, so that the model results are in good agreement with the measurements. Juv-BH4 and Juv-BH5 are represented by a single Senorge grid cell, although there is an altitudinal difference of about $100 \mathrm{~m}$ between the two boreholes. The Senorge grid cell hence features a $130 \mathrm{~m}$ lower altitude than Juv-BH4, which in addition to the much shallower snow depth at the borehole can explain the considerable warm bias in the CryoGrid 2 simulations. Furthermore, if the grid cell is run with bedrock as surface cover (as at the borehole site), the $2 \mathrm{~m}$ temperature is about $0.5^{\circ} \mathrm{C}$ lower. The warm bias of the simulation at Juv-BH5 can most likely be explained by differences in altitude and snow cover. Finally, the lowermost borehole at Juvflye, Juv-BH6, which features a similar altitude and snow cover, shows a good agreement with the simulations (Table 2). The PACE borehole at Juvasshøe is one of the few boreholes in Norway where a decadal time series is available. At depths of 7 to $10 \mathrm{~m}$, the permafrost temperatures have warmed by about $0.6 \mathrm{~K}$ in the last decade (Isaksen et al., 2007; Christiansen et al., 2010). In this period, the modeled temperature increase in CryoGrid 2 is about $1 \mathrm{~K}$, which is of comparable magnitude.

At Jetta, permafrost is found at the highest borehole located close to the summit at an altitude of $1560 \mathrm{~m}$ a.s.l. While the measured average $2 \mathrm{~m}$ ground temperatures are close to $0^{\circ} \mathrm{C}$, the CryoGrid 2 simulations fail to reproduce permafrost conditions at this site. The warm bias of the simulations can partly be explained by the different ground conditions assumed in the model, which places the corresponding grid cells in sediment class 11 (till and coarse colluvium, thick, Table 1), while all three boreholes are drilled in bedrock. Simulations for the respective grid cells with bedrock (class 130) as surface material yield $2 \mathrm{~m}$ ground temperatures of $0.6^{\circ} \mathrm{C}$ for Jet-BH1, $0.9^{\circ} \mathrm{C}$ for Jet-BH2 and $1.6^{\circ} \mathrm{C}$ for Jet$\mathrm{BH} 3$. While the agreement is good for the two other sites, the model still fails to reproduce permafrost at the uppermost borehole. However, the borehole site is $80 \mathrm{~m}$ higher than the corresponding Senorge grid cell (Table 2). When the air temperature from Senorge is scaled to the borehole altitude (using a constant lapse rate of $-6.5 \mathrm{~K} \mathrm{~km}^{-1}$ ), CryoGrid 2 produces degrading permafrost (average 2008-2010 $2 \mathrm{~m}$ temperature $0.2^{\circ} \mathrm{C}, 10 \mathrm{~m}$ temperature $-0.1^{\circ} \mathrm{C}$ ) for the lowconductivity run and stable permafrost (average 2008-2010 $2 \mathrm{~m}$ temperature $-0.4{ }^{\circ} \mathrm{C}$ ) for the high-conductivity run. Thus, CryoGrid 2 can widely reproduce the permafrost conditions on Jetta, if both sediment cover and altitude are adapted to the true borehole conditions.

At the easternmost site, Tron, an overall good agreement between measured and modeled ground temperatures is found for the low-conductivity simulation. At the uppermost borehole, Tron-BH1, permafrost is currently in a state of degradation, with positive average temperatures at $2 \mathrm{~m}$ depth, but subzero temperatures in deeper ground layers. This corresponds well to the model simulation, which yields a similar state of permafrost degradation (see Sect. 4.2). However, the Senorge grid cell is located at a lower altitude than the borehole, so that a small cold bias of the model results is likely. The same is found for the two other boreholes, which either feature a lower ground temperature in the simulation (Tron$\mathrm{BH} 2$ ), or a similar ground temperature despite of an overall shallower snow cover at the borehole site (Tron-BH3). For the high-conductivity simulation, a cold bias exceeding $1 \mathrm{~K}$ is found.

Using a transect of 11 boreholes at altitudes between 1039 and $1505 \mathrm{~m}$ a.s.l. in the Dovre Mountains, Sollid et al. (2003) determined the lower altitudinal limit of the continuous permafrost to about $1450-1550 \mathrm{~m}$ a.s.l., with patchy permafrost reaching down as far as $1300 \mathrm{~m}$. Along this transect, the CryoGrid 2 simulations place the lower permafrost limit between 1350 and $1400 \mathrm{~m}$ in the low-conductivity run, which is in good agreement with the permafrost limit determined from the borehole transect. 
An additional validation point exists for Gaustatoppen $\left(59^{\circ} 51^{\prime} \mathrm{N}, 8^{\circ} 39^{\prime} \mathrm{E}\right.$, summit at $1883 \mathrm{~m}$ a.s.l., Fig. 1), a steep, isolated mountain where permafrost was discovered above approx. $1600 \mathrm{~m}$ a.s.l. during construction of a tunnel in the 1950s (Etzelmüller et al., 2003a). This isolated permafrost occurrence is reproduced by the CryoGrid 2 runs, with several grid cells along the about $3 \mathrm{~km}$-long summit ridge featuring permafrost in the 1960s in both high- and lowconductivity runs. In the 2000s, a single grid cell with permafrost remains in the low-conductivity run.

We conclude that CryoGrid 2 simulations reproduce the lower altitudinal limit of permafrost to within approximately $100 \mathrm{~m}$. Since the permafrost boundary consists of a pattern of permafrost patches and permafrost-free areas at scales much smaller than the model resolution of $1 \mathrm{~km}^{2}$, which can extend over more than $100 \mathrm{~m}$ in altitude (see Sect. 4.1.2), a significantly better model performance cannot be achieved without increasing the spatial resolution. The overall agreement for the low-conductivity run with observed borehole temperatures is better than for the high-conductivity run.

\subsubsection{Bottom temperature of snow (BTS) measurements}

From BTS measurements (see Haeberli, 1973), probability maps for permafrost occurrence can be compiled for areas of several to many square kilometers based on multiple logistic regression, relating permafrost occurrence to topo-climatic factors (e.g., Brenning et al., 2005; Etzelmüller et al., 2001). This makes them well suited to validate the CryoGrid 2 model runs at $1 \mathrm{~km}^{2}$ resolution. Fig. 2 shows a comparison between CryoGrid 2 results (low-conductivity run) and probability maps compiled from BTS measurements (Isaksen et al., 2002) for areas at Juvflye and Dovre. The dots indicate the actual measurements of the temperature under the snowpack, which gives a good impression of the smallscale variability of permafrost conditions at the lower altitudinal limit of the mountain permafrost. In both cases, a fringe of patchy permafrost extends between the continuous permafrost and the permafrost-free zone that extends over an altitudinal difference of 100 to $200 \mathrm{~m}$. The CryoGrid 2 simulations of ground temperatures place the lower limit of the mountain permafrost within this fringe, which in the case of the Juvflye area is usually located within a single $1 \mathrm{~km}$ grid cell. With a, on average, $100 \mathrm{~m}$ lower permafrost limit (Table 2), the high-conductivity simulation can also be considered in good agreement with the BTS probability maps at Juvflye. However, at Dovre, where the topography is more gentle than at Juvflye, the low-conductivity simulation better matches the observed permafrost distribution (Fig. 2).

For the Sølen massif located in Eastern Norway, close to Lake Femund $\left(61^{\circ} 55^{\prime} \mathrm{N}, 11^{\circ} 31^{\prime} \mathrm{E}\right.$, summit at $1755 \mathrm{~m}$ a.s.l., Fig. 1), Heggem et al. (2005) used BTS measurements to determine the lower limit of permafrost at about $1100 \mathrm{~m}$ a.s.l. For this area, the high-conductivity run of CryoGrid 2 suggests a lower permafrost limit between 1100 to $1200 \mathrm{~m}$ a.s.l.,

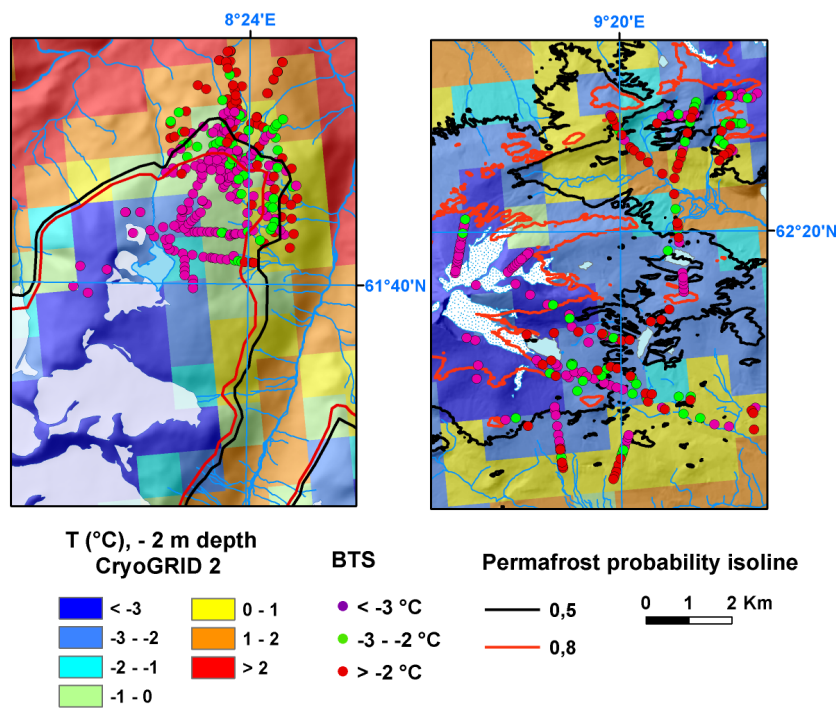

Fig. 2. Comparison of permafrost probability maps compiled from BTS measurements (dots) and the low-conductivity run of CryoGrid 2 (average $2 \mathrm{~m}$ temperature 2000-2009) for the Juvflye (left) and Dovre (right) sites.

while the low-conductivity run places the permafrost limit about $100 \mathrm{~m}$ higher. While the modeled permafrost limit is too high in particularly the low-conductivity run, Heggem et al. (2005) suggest that block fields play an important role for the occurrence of permafrost at the Sølen massif. However, in the sediment classification employed in CryoGrid 2 all grid cells at Sølen are located in class 140 (till and coarse colluvium (diamicton), thin, Table 1), which features relatively moist surface conditions, while dry ground surface conditions due to coarse blocky materials are dominant in reality (Juliussen and Humlum, 2008). If CryoGrid 2 is run with the sediment class 73 (block fields) for the Sølen area, an excellent agreement with the validation data is achieved in the low-conductivity simulation: stable permafrost (negative average temperature at 2 and $10 \mathrm{~m}$ depth) is present for grid cells with altitudes of more than $1250 \mathrm{~m}$ a.s.l., while the permafrost is degrading below (average temperature at $2 \mathrm{~m}$ depth positive, at $10 \mathrm{~m}$ negative). At one grid cell, representing $1090 \mathrm{~m}$ a.s.l., the permafrost is just about to disappear at the end of the simulated period, with a $10 \mathrm{~m}$ temperature of $-0.002^{\circ} \mathrm{C}$.

For the Elgåhøgna massif in the Femund area $\left(62^{\circ} 09^{\prime} \mathrm{N}\right.$, $11^{\circ} 57^{\prime} \mathrm{E}$, summit at $1460 \mathrm{~m}$ a.s.l., Fig. 1), the situation is similar to the Sølen area. While Heggem et al. (2005) suggest a lower permafrost limit between 1150 and $1300 \mathrm{~m}$ a.s.l., the low-conductivity CryoGrid 2 simulation does not reproduce permafrost conditions for the highest Senorge grid cell at Elgåhøgna (1320 m a.s.l., sediment class 140). If the simulation is repeated with sediment class 73 (block fields), however, a lower permafrost limit between 1200 and $1300 \mathrm{~m}$ is found, which is in good agreement with the validation data. 
Table 3. Number of grid cells with average $2 \mathrm{~m}$ ground temperature below $0{ }^{\circ} \mathrm{C}$ (corresponding to the area in $\mathrm{km}^{2}$ ) for mires (class 90), bedrock (class 130), areas covered by moist (classes 11, 12, 15, 81, 140) and dry (classes 20, 21, 22, 50, 70, 71, 73) surface sediments.

\begin{tabular}{cccccc}
\hline Period & Total & Mires & Bedrock & Moist & Dry \\
\hline \multicolumn{7}{l}{$k_{\text {snow }}=0.3 \mathrm{~W} \mathrm{~m}^{-1} \mathrm{~K}^{-1}$} & & & & \\
$1960-1969$ & 9100 & 543 & 4928 & 2813 & 816 \\
$1970-1979$ & 8147 & 534 & 4467 & 2315 & 831 \\
$1980-1989$ & 8279 & 524 & 4686 & 2256 & 813 \\
$1990-1999$ & 8481 & 464 & 4820 & 2379 & 818 \\
$2000-2009$ & 5285 & 220 & 2719 & 1580 & 766 \\
$k_{\text {snow }}=0.5 \mathrm{~W} \mathrm{~m}^{-1} \mathrm{~K}^{-1}$ & & & & \\
$1960-1969$ & 21213 & 2469 & 8591 & 8774 & 1377 \\
$1970-1979$ & 19802 & 2441 & 7680 & 8166 & 1515 \\
$1980-1989$ & 19914 & 2472 & 7945 & 7996 & 1501 \\
$1990-1999$ & 17598 & 2271 & 7718 & 6292 & 1317 \\
$2000-2009$ & 10654 & 1674 & 4626 & 3247 & 1107 \\
\hline
\end{tabular}

\subsubsection{Landforms indicative for sporadic permafrost}

In mires, permafrost occurs at significantly lower elevations compared to areas underlain by bedrock or till because of the larger thermal offset due to the thermal characteristics of organic material (e.g., Williams and Smith, 1989). While little information about the ground temperature regime in mires is available for Southern Norway, palsa mires with ice-filled mounds visible at the surface are clear evidence for sporadic permafrost. These palsa mires are mostly smaller than $1 \mathrm{~km}^{2}$, so that it crucially depends on the employed sediment classification (Sect. 3.2) if their occurrence can be reproduced. For the area between the Dovre Mountains in the west and the Glomma Valley in the east, Sollid and Sørbel (1998) provide an overview over the occurrence of palsa mires and the evolution of the surface features from the 1960s and the late 1990s. For all the described sites, a considerable degradation of the palsa mounds has been observed, which suggests that the permafrost is at least at the edge of stability under the climate forcing of the study period. Since the study is restricted to surface observations and does not provide evidence on the ground temperature regime, a comparison with the CryoGrid 2 simulations must remain qualitative. At the three main study sites (Fig. 1), Haugtjørnin $\left(62^{\circ} 21^{\prime} \mathrm{N}, 9^{\circ} 45^{\prime} \mathrm{E}\right.$, 1100 m a.s.l. $)$, Dalsætra $\left(62^{\circ} 19^{\prime} \mathrm{N}, 10^{\circ} 03^{\prime} \mathrm{E}, 950 \mathrm{~m}\right.$ a.s.l. $)$ and Haukskardsmyra $\left(62^{\circ} 09^{\prime} \mathrm{N}, 9^{\circ} 23^{\prime} \mathrm{E}, 1050 \mathrm{~m}\right.$ a.s.l. $)$, both the low- and high-conductivity runs reproduce permafrost conditions in grid cells with sediment code 90 (organic accumulation, Table 1) in the period 1980-1989, while a considerable warming of permafrost temperatures towards $0^{\circ} \mathrm{C}$ and permafrost thawing from the surface is modeled in 2000-2009.

In the following, we restrict ourselves to a comparison with the low-conductivity run. At the Haugtjørnin site, a total of six Senorge grid cells marked as mires exist at altitudes be- tween 1100 and $1300 \mathrm{~m}$ a.s.l. While the average $2 \mathrm{~m}$ ground temperatures were between -0.3 and $-0.5^{\circ} \mathrm{C}$ in the $1980 \mathrm{~s}$, they increased to $-0.1{ }^{\circ} \mathrm{C}$ and more in the $2000 \mathrm{~s}$, but remained negative. It must remain open in how far this corresponds to the observed thawing of elevated palsa plateaus (Sollid and Sørbel, 1998) at the site, for which lateral heat fluxes and changes in the surface hydrology most likely also played a triggering role. However, both the occurrence of permafrost and a significant warming trend is reproduced by the simulations. The same applies to the Dalsætra site, located in the Einunna Valley at an altitude of approximately $940 \mathrm{~m}$ a.s.l. Here, fossil palsa plateaus are described where the surface mounds had disappeared prior to the 1960s, but it is not clear whether permafrost conditions persisted in the ground. In total, three grid cells classified as mires are present in the CryoGrid 2 models, which feature similar elevations to the observed palsa mires. While the average $2 \mathrm{~m}$ ground temperatures were $-0.3^{\circ} \mathrm{C}$ in the 1980 s at all three sites, they had increased to between -0.05 and $0.02^{\circ} \mathrm{C}$ in the $2000 \mathrm{~s}$, thus indicating slowly degrading permafrost under presentday climate conditions. At a depth of $10 \mathrm{~m}$, permafrost with temperatures close to $0{ }^{\circ} \mathrm{C}$ still persists all three sites. At the third site, Haukskardsmyra, erosion of the surface features is documented (Sollid and Sørbel, 1998), but palsas can still be observed today. Three mire grid cells at corresponding altitudes exist in CryoGrid 2, which display a similar evolution of ground temperatures as the Dalsætra site, with average $2 \mathrm{~m}$ ground temperatures just at $0^{\circ} \mathrm{C}$ in the 2000s, but permafrost remaining at $10 \mathrm{~m}$ depth.

Although measurements of ground temperatures from mires are lacking for Southern Norway, the CryoGrid 2 simulations reproduce permafrost occurrence for sites with documented palsa mires, as well as a slow degradation under present-day climate forcing. A more strict validation of the model results with measured ground temperature profiles is desirable to better assess the representation of the dynamics of permafrost warming and degradation in mires and bogs.

\subsection{Evolution of permafrost extent and temperatures}

The evolution of the permafrost extent and temperatures according to the simulations with CryoGrid 2 is displayed in Fig. 3 and in Table 3. The main permafrost areas are located in mountain ranges between Hallingskarvet in the south and Dovrefjell in the north, with major, coherent permafrost areas between Finse (north of Hardangerjøkull) and Jotunheimen. Small or isolated permafrost areas exist south of the Hardangervidda Plateau (Haukelifjell) and north and east of the Dovrefjell/Rondane region (Trollheimen, Sylane). Furthermore, unglaciated alpine mountain areas towards the western coast (Sognefjord, Jostedalsbreen, alpine peaks in Møre and Romsdal) and south of Hardangervidda (e.g., Gaustatoppen) are underlain by permafrost. Finally, high-lying mire areas on flat mountain plateaus (peneplains) at approximately $1000 \mathrm{~m}$ a.s.l. (see Etzelmüller et al., 2007) in the counties of 

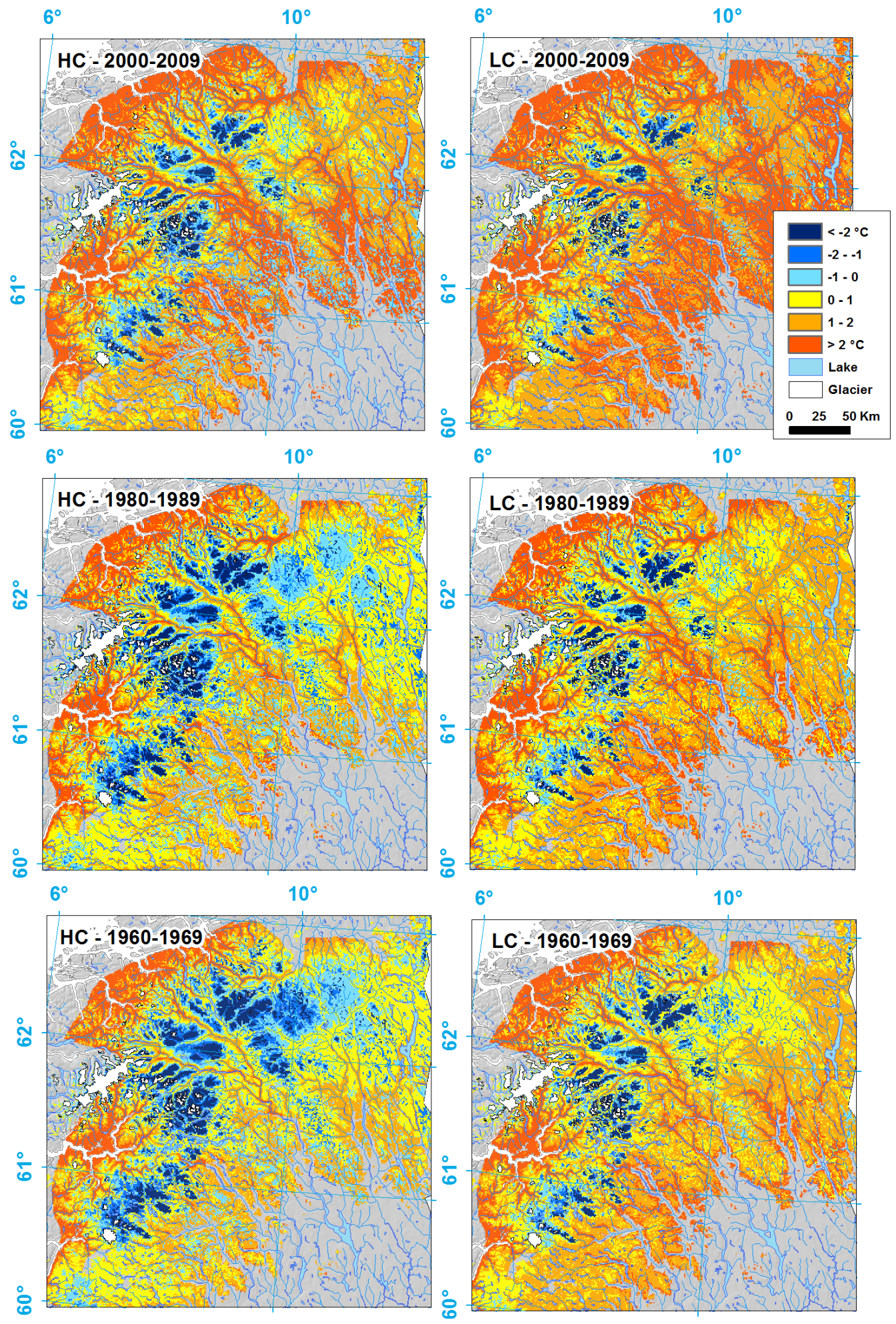

Fig. 3. Evolution of the ground temperatures in Southern Norway as given by $2 \mathrm{~m}$ average ground temperatures for the low- and high-conductivity runs ( $\mathrm{LC}$ and $\mathrm{HC}$ ). 
Buskerud, Oppland, Hedmark and Sør-Trøndelag are modeled with ground temperatures below $0{ }^{\circ} \mathrm{C}$.

A large difference in the total area exists between the lowand the high-conductivity runs, with about twice as many grid cells with $2 \mathrm{~m}$ temperatures below $0{ }^{\circ} \mathrm{C}$ in the highconductivity run for all decadal periods between the 1960s and the 2000s (Fig. 3, Table 3). This can be explained by the large areas in Southern Norway that feature altitudes just at the edge of the permafrost occurrence in the study period. The low-conductivity run places these cells in the permafrost-free zone, while permafrost occurs in the highconductivity run. The largest uncertainty in the permafrost extent exists in the eastern areas in the lee of the coastal mountains, where the high-conductivity run suggests large areas with almost continuous permafrost occurrence until the 1980s, while permafrost remains patchy in the lowconductivity run. This is mostly apparent in the regions east of Dovre and Trollheimen, which is identified as an area with high permafrost dynamics. Similar patterns are obvious in the alpine mountain belt of the northwestern part of Southern Norway (county of Møre and Romsdal). Here the highconductivity run reveals permafrost in peak areas, which are known for unstable rock faces (Isaksen et al., 2011). Although the model validation (Sect. 4.1.1) suggests an overall better agreement of the low-conductivity run with ground data, it is instructive not to discard the high-conductivity run in the light of the considerable uncertainty caused by the forcing data, the ground thermal parameters and physical processes not considered in CryoGrid 2 (see Sect. 5). Thus, we display the uncertainty in the modeled permafrost extent by introducing three classes: permafrost (in both runs), possible permafrost (only in high-conductivity run) and no permafrost (in both runs), which are displayed in Fig. 4.

Nevertheless, the modeled dynamics of the permafrost area is similar in both runs, which suggests that a robust assessment of the relative changes in the permafrost extent can be derived from the CryoGrid 2 simulations. The total area with $2 \mathrm{~m}$ ground temperatures below $0{ }^{\circ} \mathrm{C}$ is rather constant between the 1960s and the 1990s, with a reduction on the order of $7 \%$ in the low-conductivity run and $15 \%$ in highconductivity run (Table 3). From the 1990s to the 2000s, a drastic reduction occurs with a decrease of almost $40 \%$ in both runs, which clearly demonstrates the rapid dynamics of the permafrost environment in Southern Norway. While the $2 \mathrm{~m}$ ground temperatures are a good indication for the surface conditions and the sustainability of the permafrost, negative ground temperatures can persist at deeper depths for an extended period, during which the ground slowly warms towards $0^{\circ} \mathrm{C}$ and any remaining ground ice melts. This is reflected in the much smaller reduction of the area with negative $10 \mathrm{~m}$ temperatures, which is only on the order of $5 \%$ between the 1990s and the 2000s. An example for the permafrost dynamics is displayed in Fig. 5, which corresponds to the Senorge grid cell comprising Tron-BH1 and Tron-BH2 (Table 2, Sect. 4.1.1). From the late 1990s onwards, a zone
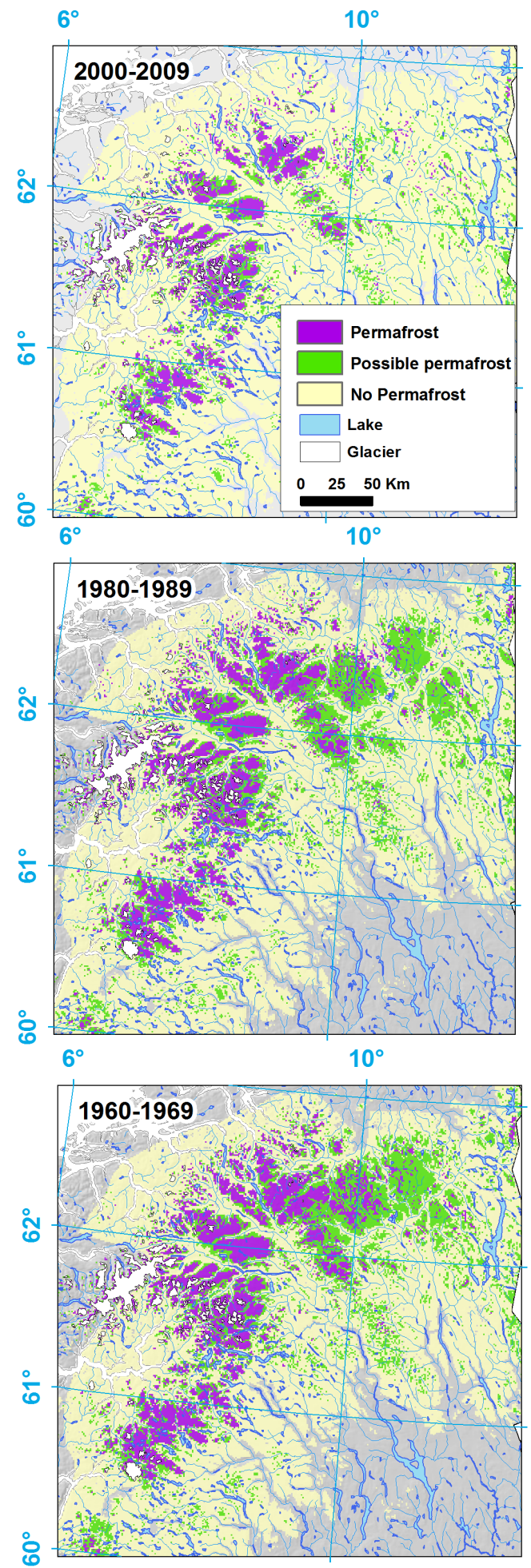

Fig. 4. Evolution of the permafrost extent in Southern Norway as given by $2 \mathrm{~m}$ average ground temperatures; PF: permafrost in both low- and high-conductivity runs; possible PF: permafrost in highand no permafrost in low-conductivity runs; no PF: no permafrost in both runs. 


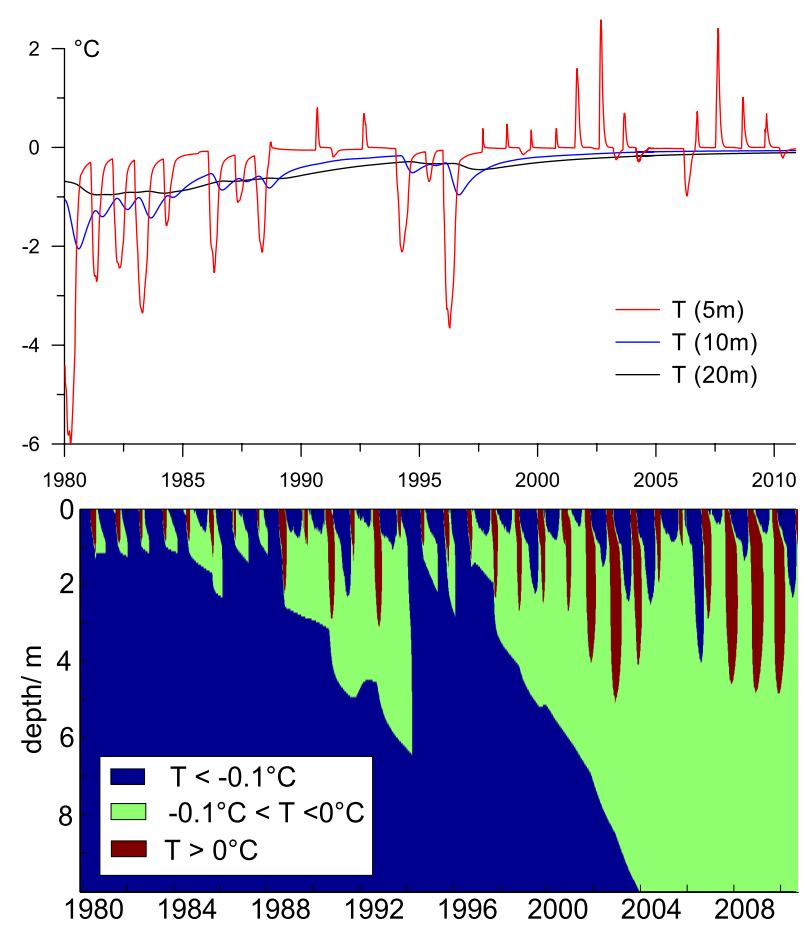

Fig. 5. Temperature evolution at three depths (upper image) and ground temperatures in the uppermost $10 \mathrm{~m}$ (lower image) of the Senorge grid cell representative of the top of Tron (Tron-BH1, Tron$\mathrm{BH} 2$, see Table 2) according to the low-conductivity run of CryoGrid 2.

with temperatures just below $0{ }^{\circ} \mathrm{C}$ begins to spread rapidly from the surface, in conjunction with a deepening of the active layer. In this more or less isothermal zone, the ground ice slowly melts and the energetic state of the ground is largely determined by the unfrozen water content. Correspondingly, the average $2 \mathrm{~m}$ ground temperature is positive, while the average ground temperatures at $10 \mathrm{~m}$ depth remain just below $0^{\circ} \mathrm{C}$ in most of the 2000s. It is such a degradational state, that about one third of the total permafrost area in Southern Norway has entered between the 1990s and the 2000s according to the CryoGrid 2 simulations. As a proxy for this state, we consider grid cells that feature negative average $10 \mathrm{~m}$, but above-zero $2 \mathrm{~m}$ ground temperatures. Fig. 6 illustrates the situation of the low-conductivity run for the 2000s, where about one third of the grid cells with negative average $10 \mathrm{~m}$ temperatures are in a degradational state.

Table 3 gives an overview of permafrost occurrence in the different sediment classes in Southern Norway. Most of the permafrost is located in bedrock, followed by till ("moist" surface sediments, approx. $90 \%$ in classes 11 and 12) and regolith/block fields ("dry" surface sediments, approx. $95 \%$ in classes 71 and 73), while mires contribute about 5 to $10 \%$ to the total area. This picture is consistent in both the low- and the high-conductivity runs. Over the study period, a severe

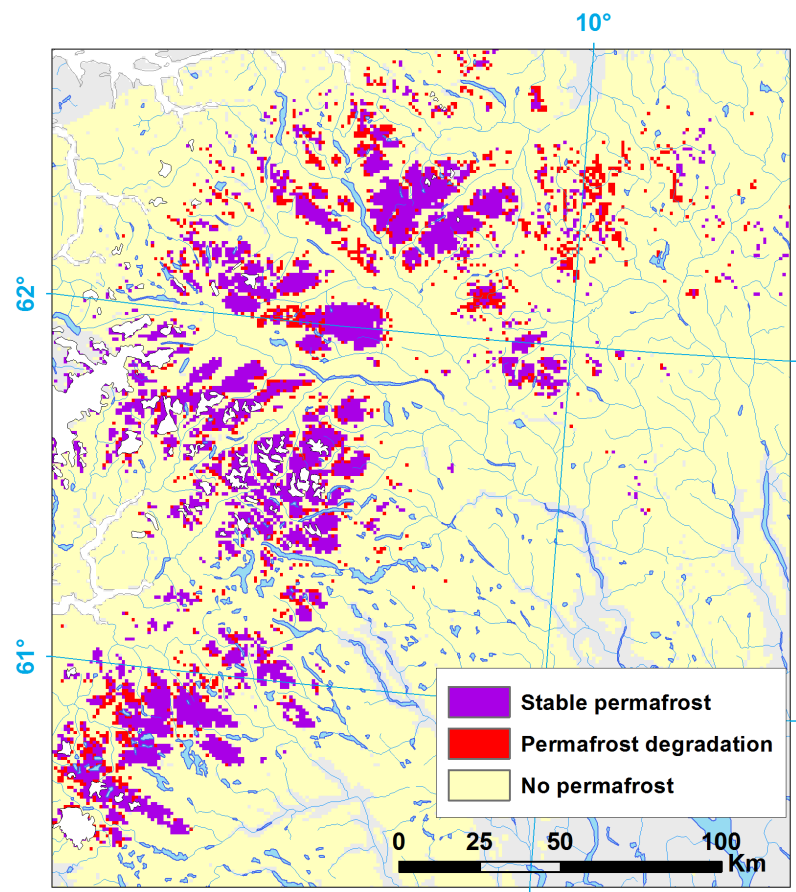

Fig. 6. Map of stable (negative $2 \mathrm{~m}$ and $10 \mathrm{~m}$ temperatures) and degrading (positive $2 \mathrm{~m}$, negative $10 \mathrm{~m}$ temperatures) permafrost areas in Southern Norway, according to average temperatures 2000-2009 from the low-conductivity run of CryoGrid 2.

reduction of the number of grid cells on the order of 45-60\% occurs for all sediment classes, except for "dry" surface sediments, where the decrease in the number of cells is considerably smaller (Table 3 ). This can be explained by a dry upper layer with low thermal conductivity, which insulates an icerich deeper layer (compare classes 71 and 73 in Table 1) and thus delays its thawing. Although the mire class 90 features a similar stratigraphy, a drastic reduction of the number of grid cells occurs between the 1990s and the 2000s, particularly in the low-conductivity run. However, the ground temperatures in the mires are much warmer than in regolith/block field grid cells (Table 4). In the 1980s and 1990s, many of the mire grid cells have already been close to the thaw threshold (Table 4, Fig.7), which they cross in the course of the further temperature increase in the 2000s, at least for depths of $2 \mathrm{~m}$. At deeper ground layers, slowly thawing permafrost still persists and the number of mire grid cells with negative average $10 \mathrm{~m}$ ground temperatures is more or less unchanged in both runs between the 1990s and the 2000s, although the temperatures are shifted towards the thawing threshold (Fig. 7). However, this permafrost is not sustainable under present-day climate conditions and will eventually disappear.

For bedrock grid cells, on the other hand, both the average temperatures (Table 4) and the form of the temperature histogram (Fig. 8) are more or less unchanged over time, although the number of grid cells with below-zero temperatures has decreased significantly. Thus, permafrost in 
Table 4. Average altitude $H$ and average $2 \mathrm{~m}$ temperature $T$ with standard deviation of grid cells with average $2 \mathrm{~m}$ temperature below $0{ }^{\circ} \mathrm{C}$ for mires (class 90), bedrock (class 130) and areas covered by moist (classes 11, 12, 15, 81, 140) and dry (classes 20, 21, 22, 50, 70, 71, 73) surface sediments.

\begin{tabular}{|c|c|c|c|c|c|c|c|c|}
\hline \multirow[t]{2}{*}{ Period } & \multicolumn{2}{|c|}{ Mires } & \multicolumn{2}{|c|}{ Bedrock } & \multicolumn{2}{|c|}{ Moist } & \multicolumn{2}{|c|}{ Dry } \\
\hline & $H$ (m a.s.l.) & $T\left({ }^{\circ} \mathrm{C}\right)$ & H (m a.s.l.) & $T\left({ }^{\circ} \mathrm{C}\right)$ & $H$ (m a.s.l.) & $T\left({ }^{\circ} \mathrm{C}\right)$ & $\mathrm{H}$ (m a.s.l.) & $T\left({ }^{\circ} \mathrm{C}\right)$ \\
\hline \multicolumn{9}{|c|}{$k_{\text {snow }}=0.3 \mathrm{Wm}^{-1} \mathrm{~K}^{-1}$} \\
\hline 1960-1969 & $1015 \pm 162$ & $-0.5 \pm 0.4$ & $1432 \pm 217$ & $-1.3 \pm 1.4$ & $1483 \pm 198$ & $-2.0 \pm 1.7$ & $1496 \pm 187$ & $-2.0 \pm 1.5$ \\
\hline 1970-1979 & $1016 \pm 163$ & $-0.3 \pm 0.3$ & $1451 \pm 211$ & $-1.2 \pm 1.3$ & $1512 \pm 192$ & $-1.8 \pm 1.6$ & $1495 \pm 185$ & $-1.6 \pm 1.4$ \\
\hline 1980-1989 & $1017 \pm 163$ & $-0.3 \pm 0.3$ & $1444 \pm 212$ & $-1.3 \pm 1.3$ & $1516 \pm 191$ & $-1.9 \pm 1.6$ & $1499 \pm 183$ & $-1.8 \pm 1.5$ \\
\hline 1990-1999 & $1033 \pm 161$ & $-0.1 \pm 0.2$ & $1447 \pm 206$ & $-1.3 \pm 1.3$ & $1521 \pm 184$ & $-2.0 \pm 1.6$ & $1501 \pm 180$ & $-1.9 \pm 1.4$ \\
\hline 2000-2009 & $1120 \pm 150$ & $-0.1 \pm 0.2$ & $1523 \pm 200$ & $-1.2 \pm 1.2$ & $1558 \pm 181$ & $-1.7 \pm 1.2$ & $1515 \pm 173$ & $-1.2 \pm 1.2$ \\
\hline \multicolumn{9}{|c|}{$k_{\text {snow }}=0.5 \mathrm{~W} \mathrm{~m}^{-1} \mathrm{~K}^{-1}$} \\
\hline 1960-1969 & $937 \pm 167$ & $-0.6 \pm 0.6$ & $1339 \pm 235$ & $-1.4 \pm 1.4$ & $1257 \pm 267$ & $-1.3 \pm 1.4$ & $1358 \pm 256$ & $-2.0 \pm 1.5$ \\
\hline 1970-1979 & $938 \pm 168$ & $-0.5 \pm 0.5$ & $1361 \pm 229$ & $-1.2 \pm 1.3$ & $1268 \pm 264$ & $-1.0 \pm 1.3$ & $1323 \pm 277$ & $-1.5 \pm 1.4$ \\
\hline 1980-1989 & $935 \pm 168$ & $-0.5 \pm 0.5$ & $1359 \pm 228$ & $-1.4 \pm 1.3$ & $1282 \pm 254$ & $-1.0 \pm 1.3$ & $1335 \pm 265$ & $-1.6 \pm 1.5$ \\
\hline 1990-1999 & $941 \pm 171$ & $-0.3 \pm 0.3$ & $1373 \pm 218$ & $-1.4 \pm 1.3$ & $1370 \pm 214$ & $-1.2 \pm 1.4$ & $1389 \pm 229$ & $-1.7 \pm 1.5$ \\
\hline 2000-2009 & $974 \pm 167$ & $-0.2 \pm 0.2$ & $1461 \pm 196$ & $-1.2 \pm 1.2$ & $1485 \pm 188$ & $-1.2 \pm 1.3$ & $1449 \pm 192$ & $-1.3 \pm 1.3$ \\
\hline
\end{tabular}
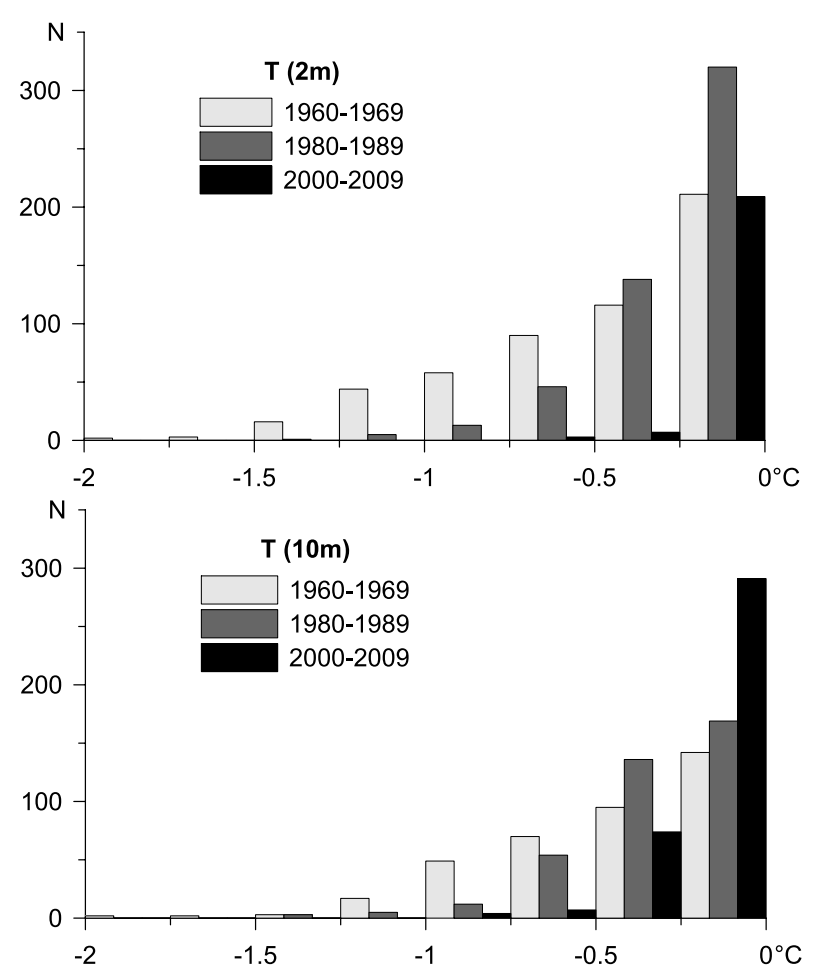

Fig. 7. Histogram (number of grid cells $N$ ) of average ground temperature at 2 and $10 \mathrm{~m}$ depths for cells classified as mires (sediment class 90 ) in the low-conductivity run.

bedrock is highly responsive to changes in the surface forcing and can quickly form or disappear, due to the high thermal conductivity and the lack of latent heat release from melting ground ice. It is instructive to note that in the mountain permafrost system in Southern Norway, a large part of the permafrost in bedrock is warmer than $-1{ }^{\circ} \mathrm{C}$ for all considered time periods. Already small changes and fast fluctuations in the surface forcing can have a considerable effect on the permafrost area in bedrock, which suggests strong changes in the permafrost area in bedrock in Southern Norway in the course of decadal to centennial climate variations. The permafrost in till cover (moist surface sediments, Table 4) shows a similar behavior to bedrock, with more or less unchanged average temperatures over time, but strong changes in the number of grid cells with negative ground temperatures.

The CryoGrid 2 simulations yield a strong increase in the thickness of the active layer between the 1980s and the 2000s. For the mire class, the modeled active layer thickness increased from, on average, 1.0 to $2.2 \mathrm{~m}$, while the increase in till was from 2.0 to $3.5 \mathrm{~m}$. For regolith/block fields, a smaller increase in active-layer thickness from, on average, 1.8 to $2.4 \mathrm{~m}$ was found. In bedrock, the active layer is deepest, with average values increasing from, on average, $4 \mathrm{~m}$ in the $1980 \mathrm{~s}$ to more than $6 \mathrm{~m}$ in the 2000s.

The altitudes at which permafrost occurs are relatively similar for bedrock, till and regolith/block fields, with average elevations between 1400 and $1500 \mathrm{~m}$ a.s.l. in the $1960 \mathrm{~s}$ increasing to $1500-1600 \mathrm{~m}$ a.s.l. in the 2000 s in the lowconductivity simulation (Table 4). In the high-conductivity simulation, these values are about $100 \mathrm{~m}$ lower. The lower altitudinal boundary of the permafrost in Southern Norway is found in mires, with average elevations on the order of 1000 and $950 \mathrm{~m}$ a.s.l. in the low- and high-conductivity runs, respectively (Table 4). 


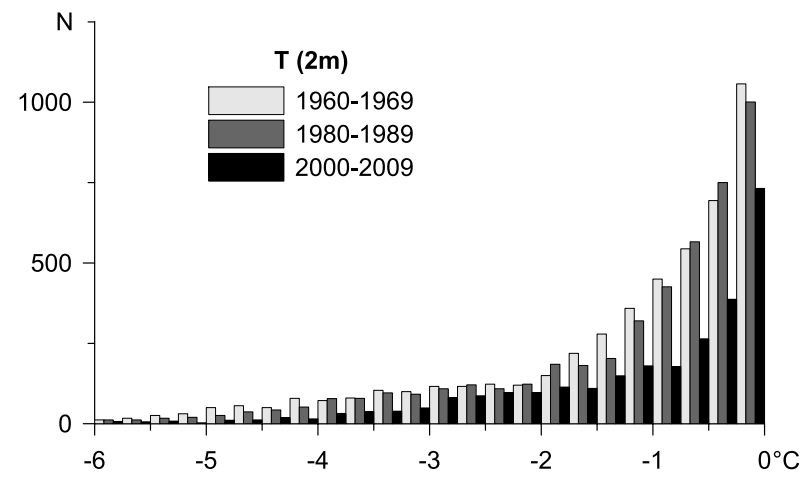

Fig. 8. Histogram (number of grid cells $N$ ) of average ground temperature at $2 \mathrm{~m}$ depth for cells classified as bedrock (sediment class 130 ) in the low-conductivity run.

\section{Discussion}

\subsection{Current model shortcomings and future improvements of CryoGrid 2}

Thermal parameters of snow: In CryoGrid 2, the thermal properties of the snow cover are described by a constant in space and time, for which a range of possible values (between 0.3 and $0.5 \mathrm{~W} \mathrm{~m}^{-1} \mathrm{~K}^{-1}$ ) is determined from in situ measurements of ground temperature profiles, air temperatures and snow depths (Sect. 3.3). The snow thermal conductivity is then treated in terms of parameter uncertainty by conducting a model run for each the lower and upper values, thus yielding an interval in which the true range of permafrost conditions is contained. While the assumed interval is small compared to the possible range of literature values for the snow thermal conductivity (e.g., Sturm et al., 1997), it has a drastic effect on the size of the modeled permafrost area, with almost a doubling of the area between the low- and the highconductivity runs (Sect. 4.2). This is explained by the prominent role of the snow thermal conductivity $k_{\text {snow }}$ for the cooling of the ground in winter, as the heat flux through the snowpack is proportional to $k_{\text {snow. }}$. Thus, an increase from 0.3 and $0.5 \mathrm{~W} \mathrm{~m}^{-1} \mathrm{~K}^{-1}$ hereby corresponds to a $67 \%$ increase of the amount of energy that can be transferred through the snowpack in a certain time interval, which gives rise to the strong differences between the low- and the high-conductivity runs.

The extensive validation of the CryoGrid 2 results with borehole temperatures, BTS measurements and other indicators of permafrost occurrence (Sect. 4.1.1) suggests that the low-conductivity run can better describe the field observations of permafrost occurrence and temperatures However, considering the extensive uncertainty in the different parameters and forcing data sets (see below), it is not a priori clear that the set of model parameters selected for the lowconductivity run represents the only parameter set that can deliver results in agreement with field evidence. In addition, the data set of borehole temperatures from which the snow thermal conductivity was estimated (Sect. 3.3) is not extensive enough to exclude both regional and altitudinal gradients in the snow thermal conductivity, nor can it exclude a trend in this important parameter over time.

The employed values of $k_{\text {snow }}$ are in the range of the sparse measurements available for permafrost areas in the wider North Atlantic region: over Arctic sea ice, Sturm et al. (2002) inferred an average value of $0.33 \mathrm{~W} \mathrm{~m}^{-1} \mathrm{~K}^{-1}$ for the snow thermal conductivity from measurements of sea ice growth. Westermann et al. (2009) found values between 0.3 and $0.55 \mathrm{~W} \mathrm{~m}^{-1} \mathrm{~K}^{-1}$ for snow on the west coast of Svalbard, which features climate conditions similar to those in the high mountain regions of Southern Norway. These values allowed us to successfully reproduce ground temperatures measured at the site with a numerical scheme similar to CryoGrid 2 (Westermann et al., 2011a). We emphasize, however, that the values in CryoGrid 2 were chosen to represent the snow thermal conductivity of wind-packed snow above tree line, so that the ground thermal regime below the tree line (and even in mire areas with permafrost), where wind redistribution of the snow is less pronounced, may not be well reproduced.

Parameterization schemes generally express the snow thermal conductivity as a function of the snow density. The functional dependence is mostly based on in situ measurements of the snow thermal conductivity, which feature a considerable spread for a certain snow density, depending on other environmental factors, but also the employed measuring technique (local vs. bulk values, Sturm et al., 1997; Saito et al., 2012). As a consequence, values of $k_{\text {snow }}$ obtained from such a density-dependent formulation can be misleading: the widely employed formula by Sturm et al. (1997), for instance, would yield a value of $0.18 \mathrm{~W} \mathrm{~m}^{-1} \mathrm{~K}^{-1}$ for a snow density of $350 \mathrm{~kg} \mathrm{~m}^{-3}$ (as measured at the key validation sites of this study, Sect. 3.3), which is still $40 \%$ lower than the value assumed in the low-conductivity simulation and clearly not appropriate for the snow cover in the study region. Furthermore, current studies question the simple functional relationship between density and thermal conductivity, while suggesting a key role of the snow's microstructural parameters (e.g., Löwe et al., 2012).

In the absence of an extensive validation data set on the snow thermal conductivity for Southern Norway, it is not appropriate to simply employ an existing snow parameterization scheme (e.g., Boone and Etchevers, 2001) for the simulation of ground temperatures with CryoGrid 2, considering the large impact on the simulation results. Furthermore, such schemes typically require the knowledge of additional environmental variables, such as wind speed or incoming radiation, which are not available at the spatial and temporal resolution of the Senorge data sets.

Thermal ground parameters: To a lesser extent, the thermal parameters of the ground determine the occurrence of permafrost in the model runs. Three different sources of uncertainty can be distinguished here: (1) the employed 
sediment classification; (2) the stratigraphy of the ground employed for each sediment class; (3) the chosen parameterization of the thermal conductivity. CryoGrid 2 makes use of an existing sediment map that was gridded to $1 \mathrm{~km}^{2}$ resolution. Thus, both potentially misrepresented areas and a strong subgrid variability of the sediment cover (see below) can cause a biased model output, which is exemplified by the validation of modeled ground temperatures with point measurements in boreholes (see Sect. 4.1.1). The same applies to the stratigraphies assigned to each sediment class (Table 1), which almost necessarily feature a strong variability within a class. Furthermore, there is only sparse field data from borehole cores for the study area that could help to confine the volumetric fractions of the soil constituents assigned to the different ground layers. However, we are confident that key properties of the different sediment classes, which give rise to the dynamic response of the ground temperatures to external climate forcing, are reproduced. Finally, a number of parameterizations for the soil thermal conductivity have been employed in similar studies (e.g., de Vries, 1952; Campbell et al., 1994; Cosenza et al., 2003; Lawrence et al., 2008), but a coherent validation study based on field or laboratory measurements is lacking for permafrost areas.

Forcing data sets: While Engelhardt et al. (2012) found an overall good agreement between Senorge snow data and glacier mass-balance measurements, a study by Saloranta (2012) suggests an overestimation of snow depths in high mountain areas by the Senorge data. On the other hand, the Senorge air temperature data may be subject to a cold bias during winter in high mountain areas, since temperature inversions are not well reproduced by the lapse-rate approach of Senorge (Sect. 3.1). The two opposite effects on ground temperature may cancel each other at least partly in the CryoGrid 2 runs, which should be investigated in future studies. The equilibrium permafrost model by Gisnås et al. (2013) found a better agreement with validation data if the snow depth above tree line was reduced by $30 \%$. With the establishment of more meteorological stations in high mountain areas, the quality of the Senorge data might improve in the next years.

Model initialization: CryoGrid is initialized to equilibrium conditions with the model forcing for the period 1958-1963, which can not account for the transient nature of the ground temperature profile at this time. While the impact of model initialization diminishes over time, in particular the grid cells for which the initialization forcing is close to the threshold of permafrost occurrence remain strongly affected: the energetic state of the ground is highly dependent on whether soil water is initialized as ice or water, although only a small difference in the initialization forcing separates these two states. In particular for mires (sediment class 90), which feature both average ground surface temperatures close to $0{ }^{\circ} \mathrm{C}$ and a low-conductive upper layer delaying the thermal response of the ground, the temperature trajectories are dependent on the initialization for more than two decades after the start of the simulations, which clearly questions the results for the mire class for the years 1960-1979.

Model physics: In CryoGrid 2, heat conduction is considered to be the only means of energy transfer in the ground. Although field and modeling studies suggest that this is a good approximation for most permafrost areas (e.g., Kane et al., 2001; Weismüller et al., 2011), other physical processes of energy transfer do occur and may play a role in at least part of the study area. Convective heat transfer through air flow due to buoyancy is documented for coarse block fields in Norway (Juliussen and Humlum, 2008; Heggem et al., 2005) and at least locally plays an important role for the thermal regime of the ground. In addition, infiltrating water from precipitation or snow melt or lateral fluxes of water can not only impact ground temperatures, but also changes in the ground thermal properties by modifying the soil water content. Furthermore, strong wintertime rain events, during which meltwater percolates to the bottom of the snowpack and refreezes, can have a significant influence on the ground temperature regime (Westermann et al., 2011a).

In CryoGrid 2, air temperatures are employed as the upper boundary of the ground thermal model instead of temperatures of the ground or snow surface, which form as a result of the surface energy balance. During a winter season on Svalbard, Westermann et al. (2009) documented a systematic offset between air and snow surface temperatures of several $\mathrm{K}$, which could constitute an important error source. However, at the same site, air temperatures and snow surface temperatures were not too different during cloudy conditions (Westermann et al., 2012), which often occur in Southern Norway during winter. In summer, different surface-soil moisture conditions can cause spatial differences of the surface temperature of on average several $\mathrm{K}$ due to differences in evaporation, even if the air temperatures are similar (Westermann et al., 2011b). Furthermore, differences in the radiation budget due to exposition could play an important role for the permafrost thermal regime on slopes, which can not be reproduced by air temperatures as model input.

The representation of additional processes in CryoGrid 2 will generally extend the model runtime, which may complicate processing of large areas at high spatial resolution. Thus, a possible performance gain should be evaluated in the light of major uncertainty sources, such as the thermal properties of the snow.

The role of the spatial resolution: While a spatial resolution of $1 \mathrm{~km}$ can adequately represent the topography in most mountain areas of Norway, only a simplified picture can be obtained in areas with steeper topography. Therefore, permafrost occurrence at single mountain tops, such as on Jetta (Table 2) is not reproduced by CryoGrid 2 (Sect. 4.1.1), but a further downscaling of the Senorge data sets with a lapse rate approach could be feasible for such sites. Furthermore, factors relevant for the thermal regime of the ground, such as exposition and snow depth, can vary on spatial scales much smaller than the model grid size. As a result, permafrost can 
be present in parts of a grid cell (Fig. 2), although simulations with grid-cell-averaged forcing data suggest the lack of permafrost. The high-conductivity simulation can be considered a lower bound for the extent of permafrost at bareblown areas or areas with very shallow snow cover. The striking difference between the modeled permafrost extent in the low- and the high-conductivity simulations illustrates the need to develop subgrid formulations for the snow cover in permafrost modeling.

\subsection{Implications of this study}

In general the distribution of mountain permafrost follows the pattern described by earlier and simpler approaches (e.g., Ødegård et al., 1996; Etzelmüller et al., 1998, 2003b). In a first quantitative analysis of permafrost extent in Norway, Gisnås et al. (2013) employed an equilibrium approach based on the Senorge data set that takes crucial factors of permafrost occurrence into account, such as the insulating snow cover and the thermal offset of the ground. For Southern Norway, the equilibrium approach yields a total of $5856 \mathrm{~km}^{2}$ for the average climate forcing of the period 1981-2010. This is well in the range of the area with negative $2 \mathrm{~m}$ ground temperatures determined in the low-conductivity simulation of CryoGrid 2, which decreases from $8481 \mathrm{~km}^{2}$ in the 1980 s to $5285 \mathrm{~km}^{2}$ in the 2000s (Table 3), while the high-conductivity run yields a significantly larger permafrost area. Compared to the equilibrium approach of Gisnås et al. (2013), CryoGrid 2 can simulate the evolution of ground temperatures in response to changing climate parameters. The results may, for example, serve a proxy for permafrost development in steep rock walls, whose stability is associated with the ground thermal regime (Haeberli et al., 2010; Krautblatter et al., 2012). Our modeling identifies degrading permafrost in the alpine area of the northwestern part of Southern Norway (county of Møre \& Romsdal) (Fig. 3), where numerous unstable rock walls are identified and even monitored (e.g., Blikra et al., 2006; Isaksen et al., 2011). Investigating further the relation between rockwall permafrost and the output of CryoGrid 2 could help to pinpoint areas where the ground thermal regime plays a role for rock slope stability.

While the model results suggest large thermal inertia for mires and areas with block fields, areas underlain by bedrock and till feature a highly dynamic system where permafrost can quickly form and disappear. Due to a relatively gentle topography in most permafrost areas (Etzelmüller et al., 2003b, 2007) and the abundance of mountain plateaus at elevations around the lower altitudinal limit of permafrost occurrence, large areas are impacted by permafrost aggradation/degradation as a response to climate variability. The strong susceptibility to climatic forcing is highlighted in both the sensitivity runs for snow thermal conductivity (Fig. 4) and the changes in response to the increase of air temperatures since the 1990s (Fig. 3). It is thus likely that large areas in Southern Norway have repeatedly undergone cy- cles of permafrost aggradation and degradation in response to climate fluctuations on timescales of decades to centuries, which would have implications for geomorphological processes and ultimately landscape development (Berthling and Etzelmüller, 2011). Such cryo-conditioning of geomorphological processes could have been a significant mechanism during the Holocene (Lilleøren et al., 2012) compared to, for example, glacier-related processes during the Pleistocene, as this study suggests a much larger area underlain by permafrost compared to the glacierized area in Southern Norway. In a similar way, geomorphological processes are impacted by seasonal frost, with number and extent of freezethaw cycles being important parameters for periglacial processes, such as solifluction (e.g., Matsuoka, 2001; Harris et al., 2008) and patterned ground dynamics (French, 1996). Seasonal frost affects a much larger area in Southern Norway compared to the permafrost extent and also extends to zones of human activity, where the winter freeze depth is, for instance, crucial for dimensioning and burial depth of sewer and water supply infrastructure. CryoGrid 2 can deliver the depth of maximum freezing during the winter season. With the setup of CryoGrid 2 presented in this study, it is possible to establish an operational ground temperature product for Norway, similar to the Senorge data sets, which could, for instance, be updated on a daily to annual basis. Such a product could be interesting for a variety of user communities, for example for landscape management, biological studies, geohazards, agriculture or construction. However, the evaluation of the model performance should be extended to areas below the tree line, as this study has concentrated on potential permafrost areas dominated by till and bedrock.

\section{Conclusions}

In this study, the transient permafrost model CryoGrid 2 is presented, which delivers ground temperatures according to forcing data of air temperatures and snow depth. The model makes use of parallel computing, so that processing of tens of thousands of grid cells is feasible. CryoGrid 2 is applied to the permafrost area in Southern Norway, where a large number of in situ data sets are available for validation and benchmarking of the model performance. Driven by operationally gridded data sets of air temperature and snow depth at a spatial resolution of $1 \mathrm{~km}^{2}$, CryoGrid 2 delivers the thermal state of the ground for the $50 \mathrm{yr}$ period 1960-2009:

- At the validation sites, the observed lower permafrost limit is reproduced to within $100 \mathrm{~m}$ by CryoGrid 2 . The modeled boundary is thus in the altitudinal fringe in which permafrost and permafrost-free zones can coexist.

- For most validation sites, borehole temperatures measured at the end of the $50 \mathrm{yr}$ model period are reproduced to within $1 \mathrm{~K}$, which is in the range of ground 
temperatures within a model grid cell given by the natural variability.

- The extent of the permafrost area is relatively constant between the 1960s the 1990s, although a slight increase of the ground temperatures is found.

- For the 1990s and the 2000s, the area with average $2 \mathrm{~m}$ ground temperatures below $0{ }^{\circ} \mathrm{C}$ is reduced by about $40 \%$. In most of this area, permafrost is slowly degrading from the top, but deeper ground layers still feature temperatures below $0^{\circ} \mathrm{C}$.

The poorly constrained thermal properties of the snowpack have been identified as the key source of uncertainty for modeling of ground temperatures with CryoGrid 2, which leads to an uncertainty in the total permafrost area in Southern Norway of a factor of two. Future improvements in the representation of the snow cover should be combined with the implementation of a subgrid formulation of snow depths in CryoGrid, which could considerably improve the representation of permafrost occurrence at the lower altitudinal limit.

Acknowledgements. This study was part of the CRYOLINK project ("Permafrost and seasonal frost in Southern Norway", grant number 185987/V30) and the CRYOMET project ("Bridging models for the terrestrial cryosphere and the atmosphere", grant number 2114465/V30), both financed by the Norwegian Research Council and the Department of Geosciences, University of Oslo (UiO). Torleif Lauritsen provided access to the petrophyscial database at the Norwegian Geological Survey (NGU). The Norwegian Meteorological Institute and the Norwegian Water and Energy Directorate (NVE) provided access to the Senorge database. Field data for validation of CryoGrid 2 were based on many different field campaigns, where especially Tobias Hipp, Herman Farbrot, Ketil Isaksen and Rune S. Ødegård contributed greatly. Gerrit Angst and Cordula Teschner arranged some of the base data used in the model in a gridded form. We greatly thank all mentioned individuals and institutions.

Edited by: D. Riseborough

\section{References}

Berthling, I. and Etzelmüller, B.: The concept of cryo-conditioning in landscape evolution, Quaternary Res., 75, 378-384, 2011.

Blikra, L. and Anda, E.: Large rock avalanches in Møre and Romsdal, western Norway, Norges geologiske undersøkelser, Bulletin, 44-45, 1997.

Blikra, L. and Nemec, W.: Postglacial colluvium in western Norway: depositional processes, facies and palaeoclimatic record, Sedimentology, 45, 909-960, 1998.

Blikra, L., Hole, P., and Rye, N.: Hurtige massebevegelser og avsetningstyper i alpine områder, Indre Nordfjord, Norges geologiske undersøkelser, 92 pp., 1989.

Blikra, L., Longva, O., Braathen, A., Anda, E., Dehls, J., and Stalsberg, K.: Rock slope failures in Norwegian fjord areas: examples, spatial distribution and temporal pattern, in: Landslides from Massive Rock Slope Failure, edited by: Evans, S., ScarasciaMugnozza, G., Strom, A., and Hermanns, R., Berlin: Springer, ISBN 1-4020-4036-9, 475-496, 2006.

B $\varnothing$, M.: Permafrost-studier på Jetta i Nord-Gudbrandsdalen, midtNorge, Cand. Scient. Thesis, University of Oslo, Norway, 127, 1998.

Boone, A. and Etchevers, P.: An intercomparison of three snow schemes of varying complexity coupled to the same land surface model: local-scale evaluation at an Alpine site, J. Hydrometeorol., 2, 374-394, 2001.

Brenning, A., Gruber, S., and Hoelzle, M.: Sampling and statistical analyses of BTS measurements, Permafrost Periglac., 16, 383393, 2005.

Campbell, G., Jungbauer Jr, J., Bidlake, W., and Hungerford, R.: Predicting the effect of temperature on soil thermal conductivity, Soil Sci., 158, 307-313, 1994.

Carlson, A. and Sollid, J.: Fullsenn - Beskrivelse til kvartærgeologisk kart 1717 III - M 1:50000, Norges geologiske undersøkelser, 1983.

Christiansen, H., Etzelmüller, B., Isaksen, K., Juliussen, H., Farbrot, H., Humlum, O., Johansson, M., Ingeman-Nielsen, T., Kristensen, L., Hjort, J., Holmlund, P., Sannel, A., Sigsgaard, C., Akerman, H., Foged, N., Blikra, L., Pernosky, M., and Ødegård, R.: The thermal state of permafrost in the nordic area during the international polar year 2007-2009, Permafrost Periglac., 21, 156$181,2010$.

Cosenza, P., Guerin, R., and Tabbagh, A.: Relationship between thermal conductivity and water content of soils using numerical modelling, Eur. J. Soil Sci., 54, 581-588, 2003.

Daanen, R. P. and Nieber, J. L.: Model for Coupled Liquid Water Flow and Heat Transport with Phase Change in a Snowpack, J. Cold Reg. Engin., 23, 43-68, 2009.

Daanen, R. P., Misra, D., Epstein, H., Walker, D., and Romanovsky, V.: Simulating nonsorted circle development in arctic tundra ecosystems, J. Geophys. Res., 113, 1-10, 2008.

Dall'Amico, M., Endrizzi, S., Gruber, S., and Rigon, R.: A robust and energy-conserving model of freezing variably-saturated soil, The Cryosphere, 5, 469-484, doi:10.5194/tc-5-469-2011, 2011.

de Vries, D.: The thermal conductivity of soil, Mededelingen van de Landbouwhogeschool te Wageningen, 52, 1-73, 1952.

Delisle, G.: Near-surface permafrost degradation: How severe during the 21st century?, Geophys. Res. Lett., 34, 9503, doi:10.1029/2007GL029323, 2007.

Engelhardt, M., Schuler, T., and Andreassen, L.: Evaluation of gridded precipitation for Norway using glacier mass-balance measurements, Geograf. Ann. A, 94, 501-509, 2012.

Engeset, R., Tveito, O., Alfnes, E., Mengistu, Z., Udnæs, H., Isaksen, K., and Førland, E.: Snow map system for Norway, in: Proceedings XXIII Nordic Hydrological Conference, vol. 8, 12, 2004a.

Engeset, R., Tveito, O., Udnæs, H., Alfnes, E., Mengistu, Z., and Isaksen, K.: Snow Map Validation for Norway, in: Proceedings XXIII Nordic Hydrological Conference, vol. 8, 12, 2004b.

Etzelmüller, B., Berthling, I., and Sollid, J.: The distribution of permafrost in Southern Norway; a GIS approach, in: Seventh International Conference on Permafrost, Proceedings. Collection Nordicana, edited by: Lewkowicz, A. and Allard, M., Centre d'Etudes Nordiques, Universite Laval, Quebec, PQ, Canada, 
251-257, 1998.

Etzelmüller, B., Hoelzle, M., Heggem, E., Isaksen, K., Mittaz, C., Mühll, D., Ødegård, R., Haeberli, W., and Sollid, J.: Mapping and modelling the occurrence and distribution of mountain permafrost, Norsk Geogr. Tidsskr., 55, 186-194, 2001.

Etzelmüller, B., Berthling, I., and Ødegård, R.: 1-D-DC-resistivity depth soundings in high mountain areas of Southern Norway a tool in permafrost investigations, Z. Geomorph., Suppl. Bind, 132, 19-36, 2003a.

Etzelmüller, B., Berthling, I., and Sollid, J.: Aspects and concepts on the geomorphological significance of Holocene permafrost in southern Norway, Geomorphology, 52, 87-104, 2003b.

Etzelmüller, B., Romstad, B., and Fjellanger, J.: Automatic regional classification of topography in Norway, Norsk Geogr. Tidsskr., 87, 167-180, 2007.

Farbrot, H., Etzelmüller, B., Hipp, T., Isaksen, K., Ødegård, R., Schuler, T., and Humlum, O.: Air and ground temperatures along elevation and continental gradients in Southern Norway, Permafrost Periglac., 22, 343-360, 2011.

Farouki, O.: The thermal properties of soils in cold regions, Cold Reg. Sci. Technol., 5, 67-75, 1981.

French, H.: The Periglacial Environment, Longmann, London, 1996.

Garnes, K. and Bergersen, O.: Distribution and genesis of tills in central south Norway, Boreas, 6, 135-147, 1977.

GCOS: Global Climate Observing System, http://gcos.wmo.int, 2012.

Gisnås, K., Etzelmüller, B., Farbrot, H., Schuler, T., and Westermann, S.: CryoGRID 1.0: Permafrost distribution in Norway estimated by a spatial numerical model, Permafrost Periglac., 24, 2-19, 2013.

Haeberli, W.: Die Basis-Temperatur der winterlichen Schneedecke als möglicher Indikator für die Verbreitung von Permafrost in den Alpen, Z. Gletscherk. Glazialgeol., 9, 221-227, 1973.

Haeberli, W., Noetzli, J., Arenson, L., Delaloye, R., Gärtner-Roer, I., Gruber, S., Isaksen, K., Kneisel, C., Krautblatter, M., and Phillips, M.: Mountain permafrost: development and challenges of a young, J. Glaciol., 56, 1043-1058, 2010.

Haldorsen, S.: Grain-size distribution of subglacial till and its relation to glacial scrushing and abrasion, Boreas, 10, 91-105, 1981.

Harris, C., Haeberli, W., Vonder Mühll, D., and King, L.: Permafrost monitoring in the high mountains of Europe: the PACE project in its global context, Permafrost Periglac., 12, 3-11, 2001.

Harris, C., Kern-Luetschg, M., Murton, J., Font, M., Davies, M., and Smith, F.: Solifluction processes on permafrost and nonpermafrost slopes: results of a large-scale laboratory simulation, Permafrost Periglac., 19, 359-378, 2008.

Heggem, E., Juliussen, H., and Etzelmüller, B.: Mountain permafrost in central-eastern Norway, Norsk Geogr. Tidsskr., 59, 94-108, 2005.

Hillel, D.: Introduction to Soil Physics, San Diego, USA, 58-63, 1982.

Hindmarsh, A., Brown, P., Grant, K., Lee, S., Serban, R., Shumaker, D., and Woodward, C.: SUNDIALS: Suite of nonlinear and differential/algebraic equation solvers, ACM T. Math. Software, 31, 363-396, 2005.

Hipp, T.: Mountain Permafrost in Southern Norway - Distribution, Spatial Variability and Impacts of Climate Change, Ph.D. thesis, Faculty of Mathematics and Natural Sciences, University of
Oslo, Norway, 2012.

Hipp, T., Etzelmüller, B., Farbrot, H., Schuler, T. V., and Westermann, S.: Modelling borehole temperatures in Southern Norway - insights into permafrost dynamics during the 20th and 21st century, The Cryosphere, 6, 553-571, doi:10.5194/tc-6-553-2012, 2012.

Isaksen, K., Hauck, C., Gudevang, E., Ødegård, R., and Sollid, J.: Mountain permafrost distribution in Dovrefjell and Jotunheimen, southern Norway, based on BTS and DC resistivity tomography data, Norsk Geogr. Tidsskr., 56, 122-136, 2002.

Isaksen, K., Sollid, J., Holmlund, P., and Harris, C.: Recent warming of mountain permafrost in Svalbard and Scandinavia, J. Geophys. Res.-Earth Surface, 112, F02S04, doi:10.1029/2006JF000522, 2007.

Isaksen, K., Blikra, L., and Eiken, T.: The existence of warm permafrost in unstable rock slopes in western and northern Norway, Geophys. Res. Abstracts, 13, p. 10942, 2011.

Jafarov, E. E., Marchenko, S. S., and Romanovsky, V. E.: Numerical modeling of permafrost dynamics in Alaska using a high spatial resolution dataset, The Cryosphere, 6, 613-624, doi:10.5194/tc6-613-2012, 2012.

Jørgensen, P.: Some properties of Norwegian tills, Boreas, 6, 149_ 157, 1977.

Juliussen, H. and Humlum, O.: Thermal regime of openwork block fields on the mountains Elgåhogna and Sølen, central-eastern Norway, Permafrost Periglac., 19, 1-18, 2008.

Jury, W. and Horton, R.: Soil Physics, John Wiley \& Sons, Hoboken, New Jersey, USA, 2004.

Kane, D., Hinkel, K., Goering, D., Hinzman, L., and Outcalt, S.: Non-conductive heat transfer associated with frozen soils, Global Planet. Change, 29, 275-292, 2001.

Krautblatter, M., Huggel, C., Deline, P., and Hasler, A.: Research perspectives on unstable high-alpine bedrock permafrost: measurement, modelling and process understanding, Permafrost Periglac., 23, 80-88, 2012.

Lawrence, D., Slater, A., Romanovsky, V., and Nicolsky, D.: Sensitivity of a model projection of near-surface permafrost degradation to soil column depth and representation of soil organic matter, J. Geophys. Res., 113, F02011, doi:10.1029/2007JF000883, 2008.

Lewkowicz, A.: Evaluation of miniature temperature-loggers to monitor snowpack evolution at mountain permafrost sites, northwestern Canada, Permafrost Periglac., 19, 323-331, 2008.

Lilleøren, K. and Etzelmüller, B.: A regional inventory of rock glaciers and ice-cored moraines in Norway, Geograf. Ann. A, 93, 175-191, 2011.

Lilleøren, K., Etzelmüller, B., Gisnås, K., Schuler, T., and Humlum, O.: The relative age of mountain permafrost-estimation of Holocene permafrost limits in Norway, Global Planet. Change, 92-93, 209-223, 2012.

Löwe, H., Riche, F., and Schneebeli, M.: A general treatment of snow microstructure exemplified by an improved relation for the thermal conductivity, The Cryosphere Discuss., 6, 4673-4693, 10.5194/tcd-6-4673-2012, 2012.

Matsuoka, N.: Solifluction rates, processes and landforms: a global review, Earth-Sci. Rev., 55, 107-134, 2001.

Matthews, J., Dahl, S., Berrisford, M., Nesje, A., Dresser, P., and Dumayne-Peaty, L.: A preliminary history of Holocene colluvial (debris-flow) activity, Leirdalen, Jotunheimen, Norway, J. Qua- 
ternary Sci., 12, 117-129, 1997.

Mohr, M.: New routines for gridding of temperature and precipitation observations for seNorge.no, Met.no Report, 40, http://met.no/Forskning/Publikasjoner/Publikasjoner (last access: 17 Dec 2012), 2008.

Mohr, M. and Tveito, O.: Daily temperature and precipitation maps with $1 \mathrm{~km}$ resolution derived from Norwegian weather observations, in: Proceedings 13th Conference on Mountain Meteorology/17th Conference on Applied Climatology, 11-15, 2008.

Mualem, Y.: A new model for predicting the hydraulic conductivity of unsaturated porous media, Water Resour. Res., 12, 513-522, 1976.

NGU: Produktspesifikasjon ND_Løsmasser, Norges Geologiske Unders $\varnothing$ kelser, 37/99, 2010.

Ødegård, R., Hoelzle, M., Johansen, K., and Sollid, J.: Permafrost mapping and prospecting in southern Norway, Norsk Geogr. Tidsskr., 50, 41-53, 1996.

Olesen, O., Brönner, M., Ebbing, J., Gellein, J., Gernigon, L., Koziel, J., Lauritsen, T., Myklebust, R., Pascal, C., Sand, M., et al.: New aeromagnetic and gravity compilations from Norway and adjacent areas: methods and applications, in: Geological Society, London, Petroleum Geology Conference series, Geol. Soc. London, vol. 7, 559-586, 2010.

Osterkamp, T. and Romanovsky, V.: Evidence for warming and thawing of discontinuous permafrost in Alaska, Permafrost Periglac., 10, 17-37, 1999.

Roaldset, E., Pettersen, E., Longva, O., and Mangerud, J.: Remnants of preglacial weathering in western Norway, Norsk Geogr. Tidsskr., 62, 169-178, 1982.

Romanovsky, V., Smith, S., and Christiansen, H.: Permafrost thermal state in the polar Northern Hemisphere during the international polar year 2007-2009: A synthesis, Permafrost Periglac., 21, 106-116, 2010.

Saito, K., Yamaguchi, S., Iwata, H., Harazono, Y., Kosugi, K., Lehning, M., and Shulski, M.: Climatic physical snowpack properties for large-scale modeling examined by observations and a physical model, Polar Science, 6, 79-95, 2012.

Saloranta, T. M.: Simulating snow maps for Norway: description and statistical evaluation of the seNorge snow model, The Cryosphere, 6, 1323-1337, doi:10.5194/tc-6-1323-2012, 2012.

Schiesser, W.: The Numerical Method of Lines: Integration of Partial Differential Equations, vol. 212, Academic Press, San Diego, USA, 1991.

Sigmond, E.: Geologisk kart over land og havområder i NordEuropa, målestokk 1: 4 millioner, Norwegian Geological Survey, Trondheim, Norge, 2002.

Slagstad, T., Balling, N., Elvebakk, H., Midttømme, K., Olesen, O., Olsen, L., and Pascal, C.: Heat-flow measurements in Late Palaeoproterozoic to Permian geological provinces in south and central Norway and a new heat-flow map of Fennoscandia and the Norwegian-Greenland Sea, Tectonophysics, 473, 341-361, 2009.

Smith, M. and Riseborough, D.: Permafrost monitoring and detection of climate change, Permafrost Periglac., 7, 301-309, 1996.
Sollid, J. and Reite, A.: Central Norway, glaciation and deglaciation, in: Glacial deposits in north-west Europe, edited by: Ehlers, J., Balkema, Rotterdam, 41-59, 1983.

Sollid, J. and Sørbel, L.: Distribution and genesis of moraines in Central Norway, Striae, 20, 63-67, 1984.

Sollid, J. and Sørbel, L.: Palsa bogs as a climate indicator: examples from Dovrefjell, southern Norway, Ambio, 27, 287-291, 1998.

Sollid, J., Isaksen, K., Eiken, T., and Ødegård, R.: The transition zone of mountain permafrost on Dovrefjell, southern Norway, in: Proceedings of the International Conference on Permafrost, vol. 2, 1085-1090, 2003.

Sturm, M., Holmgren, J., König, M., and Morris, K.: The thermal conductivity of seasonal snow, J. Glaciol., 43, 26-41, 1997.

Sturm, M., Perovich, D., and Holmgren, J.: Thermal conductivity and heat transfer through the snow on the ice of the Beaufort Sea, J. Geophys. Res.-Oceans, 107, 8043, 2002.

Thoresen, M.: Kvartærgeologisk kart over Norge, tema jordarter, Norwegian Geological Survey, Trondheim, Norge, 1990.

Tveito, O. and Førland, E.: Mapping temperatures in Norway applying terrain information, geostatistics and GIS, Norsk Geogr. Tidsskr., 53, 202-212, 1999.

Van Genuchten, M.: A closed-form equation for predicting the hydraulic conductivity of unsaturated soils, Soil Sci. Soc. Am. J., 44, 892-898, 1980.

Vorren, T.: Grain-size distribution and grain-size parameters of different till types on Hardangervidda, South-Norway, Boreas, 6, 219-227, 1977.

Weismüller, J., Wollschläger, U., Boike, J., Pan, X., Yu, Q., and Roth, K.: Modeling the thermal dynamics of the active layer at two contrasting permafrost sites on Svalbard and on the Tibetan Plateau, The Cryosphere, 5, 741-757, doi:10.5194/tc-5741-2011, 2011.

Westermann, S., Lüers, J., Langer, M., Piel, K., and Boike, J.: The annual surface energy budget of a high-arctic permafrost site on Svalbard, Norway, The Cryosphere, 3, 245-263, doi:10.5194/tc3-245-2009, 2009.

Westermann, S., Boike, J., Langer, M., Schuler, T. V., and Etzelmüller, B.: Modeling the impact of wintertime rain events on the thermal regime of permafrost, The Cryosphere, 5, 945-959, doi:10.5194/tc-5-945-2011, 2011.

Westermann, S., Langer, M., and Boike, J.: Spatial and temporal variations of summer surface temperatures of high-arctic tundra on Svalbard - Implications for MODIS LST based permafrost monitoring, Remote Sens. Environ., 115, 908-922, 2011 b.

Westermann, S., Langer, M., and Boike, J.: Systematic bias of average winter-time land surface temperatures inferred from MODIS at a site on Svalbard, Norway, Remote Sens. Environ., 118, 162167, 2012.

Williams, P. and Smith, M.: The Frozen Earth: Fundamentals of Geocryology, Cambridge University Press, Cambridge, 1989.

Zhang, Y., Chen, W., and Cihlar, J.: A process-based model for quantifying the impact of climate change on permafrost thermal regimes, J. Geophys. Res, 108, 4695, doi:10.1029/2002JD003354, 2003. 